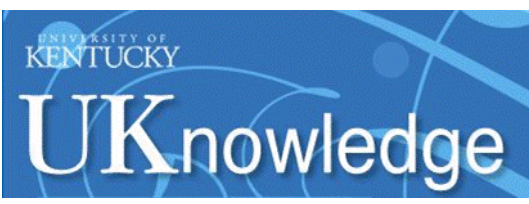

Kentucky Law Journal

\title{
Confederation-Era Discrimination Against Interstate Commerce and the Legitimacy of the Dormant Commerce Clause Doctrine
}

Brannon P. Denning

Samford University

Follow this and additional works at: https://uknowledge.uky.edu/klj

Part of the Commercial Law Commons, and the Legal History Commons

Right click to open a feedback form in a new tab to let us know how this document benefits you.

\section{Recommended Citation}

Denning, Brannon P. (2005) "Confederation-Era Discrimination Against Interstate Commerce and the Legitimacy of the Dormant Commerce Clause Doctrine," Kentucky Law Journal: Vol. 94: Iss. 1, Article 4. Available at: https://uknowledge.uky.edu/klj/vol94/iss1/4 


\title{
Confederation-Era Discrimination Against Interstate Commerce and the Legitimacy of the Dormant Commerce Clause Doctrine
}

\author{
Brannon P. Denning
}

It is an article of faith among critics of the dormant Commerce Clause doctrine (DCCD) that it is utterly lacking in textual or historical support. Critics argue that (1) the doctrine has no textual foundation; (2) there is no indication that the Framers intended the Supreme Court to read into the positive grant of power to Congress over commerce any implicit, judicially enforceable restrictions on states; and (3) if indeed such restrictions were intended, they were not widely understood to be there; for if the public were to have had such an understanding it would have revolted against such a restriction on state power. Some critics have been so bold as to suggest that the doctrine's provenance is so questionable that the Supreme Court ought to abandon it once and for all.

An even stronger version of this argument tracks a long-running dispute among historians regarding the degree to which states actually discriminated against one another during the Confederation period. Revisionist historians denied that any appreciable discrimination took place and argued that states were actually cooperating with one another, contrary to the standard account holding that a shooting war would have erupted from various commercial disputes among the newo states. Strong critics of the DCCD argue that this historical evidence showes the DCCD to be nothing less than a constitutional fraud.

In this work, I will demonstrate ( $I$ ) that fears of present and future disputes among states over interstate commerce occupied the minds of the Framers, who saw the need for locating the power to regulate interstate commerce in Congress; (2) that this discrimination was not the product of the fevered imagination of nationalists bent on reining in the states, but that it really existed, and that it showed no signs of abating on the eve of the Philadelphia Convention; (3) that the abuses of the Confederation era were specifically addressed in the text of the Constitution; and (4) that the text of

I Associate Professor of Law, Cumberland School of Law at Samford University. Thanks to Jim Chen, Dan Coenen, Jacob Cogan, Morris Cohen, Calvin Johnson, Pat Kelly, Glenn Reynolds, Bill Ross, Ted Ruger, Norman Williams, and Ed Zelinsky for comments on earlier drafts. Thanks also to Allen Sullivan for outstanding research assistance. 
the Constitution and the history surrounding its adoption furnish an ample textual and historical basis for much of the DCCD as it has developed.

$I^{\prime}$ $T$ is an article of faith among critics of the dormant Commerce Clause doctrine (DCCD)-the name given to the judicially enforced restrictions on states' abilities to discriminate against or otherwise burden interstate commerce-that the doctrine is utterly lacking in textual or historical support. Critics' arguments can be summarized as follows. First, the doctrine has no textual foundation. ${ }^{2}$ Second, there is no indication that the Framers intended the Court to read into the positive grant of power to Congress over commerce any implicit, judicially enforceable restrictions on states. ${ }^{3}$ Third, if indeed such restrictions were intended, they were not widely understood to be there; for if the public were to have had such an understanding it would have revolted against such a restriction on state power. ${ }^{4}$ Some critics have been so bold as to suggest that the doctrine's provenance is so questionable that the Supreme Court ought to abandon it once and for all. ${ }^{5}$

An even stronger version of this argument tracks a long-running dispute among historians regarding the degree to which states actually discriminated against one another during the Confederation period. ${ }^{6}$ Revisionist

2 See, e.g., Camps Newfound/Owatonna, Inc. v. Harrison, 520 U.S. 564, 610 (I997) (Thomas, J., dissenting) (DCCD has "no basis in the text of the Constitution"); Okla. Tax Comm'n v. Jefferson Lines, Inc., 514 U.S. I 75, 200 (1995) (Scalia, J., concurring in part and dissenting in part) (calling the DCCD the "negative" Commerce Clause because it "does not appear in the Constitution"); Martin H. Redish \& Shane V. Nugent, The Dormant Commerce Clause and the Constitutional Balance of Federalism, 1987 DuKE L.J. 569, 617 (arguing that the DCCD "lacks a foundation or justification in either the Constitution's text or history"); see also Julian N. Eule, Laying the Dormant Commerce Clause to Rest, 9 I YALE L.J. 425 (1982); Richard D. Friedman, Putting the Dormant Commerce Clause out of Its Misery, I 2 Cardozo L. Rev. 745 (1991).

3 See, e.g., Amy M. Petragnani, The Dormant Commerce Clause: On Its Last Leg, 57 ALB. L. REv. 1215, 1216 (1994) (arguing the DCCD is "absolutely without support in the text of the Constitution or the intent of the Framers").

4 Tyler Pipe Indus., Inc. v. Wash. State Dep't of Revenue, 483 U.S. 232, 264 (1987) (Scalia, J., concurring in part and dissenting in part) ("I think it beyond question that many 'apprehensions' would have been 'entertained' if supporters of the Constitution had hinted that the Commerce Clause, despite its language, gave this Court the power it has since assumed."); Felix Frankfurter, The Commerce Clause Under Marshall, Taney, and Waite 19 (Peter Smith Publisher 1978) (1937) (describing the DCCD as "an audacious doctrine, which, one may be sure, would hardly have been publicly avowed in support of the adoption of the Constitution").

5 See, e.g., Hillside Dairy, Inc. v. Lyons, 539 U.S. 59, 62-63 (2003) (Thomas, J., concurring) (stating that he will no longer enforce the DCCD because it "has no basis in the text of the Constitution, makes little sense, and [is] virtually unworkable in application"; quoting Camps Newfound/Owatonna, 520 U.S. at 610 (Thomas, J., dissenting)).

6 See, e.g., Edmund W. Kitch, Regulation and the American Common Market, in Regulation, Federalism, and InTerstate Commerce I5-20 (A. Dan Tarlock ed., 1981). Kitch, citing the 
historians denied that any appreciable discrimination took place and maintained that states were actually cooperating with one another, contrary to the standard account popularized by John Fiske in the late nineteenth century, which held that a commercial war was waged among the new states. Embracing the revisionists' account, strong critics of the DCCD argue that, given the lack of historical evidence to support Fiske's "Critical Period" thesis, the DCCD is nothing less than a constitutional fraud.

Given that the DCCD is one of the oldest continuously applied doctrines in American constitutional law, there is probably little real danger of it being supplanted. However, given its potential to severely restrict state regulation of everything from online automobile sales ${ }^{9}$ to state regulation of garbage, ${ }^{10}$ highway safety, "and taxation ${ }^{12}$ - just to name a few areas in which the DCCD looms large-doubts about its legitimacy should be put to rest. If they cannot, then arguments for the doctrine's narrow application-even its elimination-become more persuasive.

This work will demonstrate ( 1 ) that fears of present and future disputes among states over interstate commerce occupied the minds of the Framers, who saw the need for locating the power to regulate interstate commerce in Congress; (2) that this discrimination was not the product of the fevered imagination of nationalists bent on reining in the states, but that it really existed, and that it showed no signs of abating on the eve of the Philadelphia Convention; (3) that the abuses of the Confederation Era were specifically addressed in the text of the Constitution; and (4) that the text of the Constitution and the history surrounding its adoption furnish an ample textual and historical basis for much of the DCCD as it has developed. Revisionist accounts of the Confederation period simply missed examples of discrimination against interstate commerce present in state commercial legislation of the Confederation period, downplayed the role they played in stoking the fears of those concerned with national union, or

work of revisionist historians, has argued that there is but a single "recorded instance of one state imposing a restriction on commerce coming from other states." Id. at I 8 . This led Kitch to conclude that "[t]he theoretical arguments that decentralized authorities should be expected to cooperate to facilitate freedom of trade appear to be confirmed by the experience under the Articles of Confederation. The argument that this experience demonstrated the opposite ... has no support in primary source materials." Id. at 19 . He then argued that the Constitution's text provided less protection for trade than the Articles of Confederation, and that the Framers left to Congress, not the courts, the job of establishing a national free market. Id. at 20.

7 John Fiske, The Critical Period in American History: 1783-1789, at 144-45 (Boston, Houghton, Mifflin 1888).

8 See Kitch, supra note 6.

9 See, e.g., Ford Motor Co. v. Tex. Dep't of Transp., 264 F.3d 493 (5th Cir. 2001).

10 See, e.g., City of Philadelphia v. New Jersey, 437 U.S. 617 (1978).

I I See, e.g., S.C. State Highway Dep't v. Barnwell Bros., 303 U.S. I 77 (1938).

12 See, e.g., S. Cent. Bell v. Alabama, 526 U.S. 160 (1999). 
minimized the role that the proposed Constitution played in ending that discrimination.

Part I of this article describes the revisionist account of the Confederation era, which minimized the extent of interstate commercial friction. Part II offers an overview of the state of the economy during the Confederation. The mid-1 780 os brought on a severe depression, during which states scrambled to raise revenue. Imposts and duties on commerce became popular, with nearly every state enacting some sort of impost or duty regime. These conflicting trade regulation regimes began to cause consternation in moderate nationalists like James Madison, who feared for the union. Their worries are described in part III and were instrumental in convincing Madison, among others, that structural reform of the Articles of Confederation was essential if the union was to survive.

A particular worry was that some states were targeting commerce coming from other states, either products originating in other states or products imported from abroad by out-of-state merchants and transported into neighboring states for sale. Part IV offers specific examples of state laws which did precisely this, contrary to revisionists' claims that such economic rivalry was exceptional and, as described in part $\mathrm{V}$, that states were actually beginning to cooperate to eliminate trade barriers by the late $1780 \mathrm{~s}$.

Part VI outlines the restrictions on state regulation of commerce the Framers of the Constitution placed in that document-restrictions that correspond precisely to the kinds of abuses seen under the Confederation. In addition, contrary to those who assume that at state sovereignty's high tide no support could be had for restrictions on state commercial regulation, this article shows that many of these restrictions had origins in early drafts of the Articles of Confederation.

Finally, part VII ties the textual and historical evidence back to the DCCD as it presently exists. At a minimum, there is ample support for judicially enforced restrictions on state regulations that discriminate against interstate commerce. Critics of the DCCD, I conclude, are obliged to construct better historical and textual arguments to support their illegitimacy thesis or must confine their criticisms to the doctrine's evolution.

\section{I. "Critical Period" or "Teapot Tempest"?}

The "Critical Period" thesis, first made popular by historian John Fiske in his 1888 book The Critical Period in American History: $1783-1789$, held that only the wisdom of that assemblage of demigods gathered in Philadelphia in May 1787 saved the United States from being torn apart by civil war spawned by the commercial jealousies that arose among the states, which 
the impotent Confederation Congress could not squelch. ${ }^{13}$ In this telling, granting Congress the power to regulate interstate commerce was largely seen as an effort to limit the states' power. Fiske's thesis has even found its way into the Supreme Court's DCCD opinions. Justice Cardozo, for example, wrote that the Constitution "was framed upon the theory that the peoples of the several states must sink or swim together, and that in the long run prosperity and salvation are in union and not division." Justice Robert Jackson, too, once penned what has been described as a "mythopoeic" tribute to economic nationalism in the 1949 case of H.P. Hood 8 ? Sons, Inc. v. Du Mond. ${ }^{15}$ On occasion, the Court has even cited Fiske in support of its conclusions that the Constitution was framed to end harmful rivalries among states and inaugurate a new era of nationalist cooperation in commercial matters.

Beginning with Charles Beard, who charged that Fiske wrote "without fear and without research," ${ }^{17}$ and Merrill Jensen, who pronounced Fiske's work to be of "no value as either history or example,"

I3 See Fiske, supra note 7, at 144-54. Merrill Jensen, a vociferous critic of Fiske, paraphrased the "Critical Period" thesis in his 1950 history of the Confederation Period:

[B]y I 786 there was universal depression, trade had wellnigh stopped, and political quackery with cheap and dirty remedies had full control of the field. Trade disputes promised to end in war between states. Territorial disputes led to bloodshed. War with Spain threatened. The "league" [i.e., the Confederation] could not coerce its members. Secession was threatened by some states. Congress had no money and could borrow none. Courts were broken up by armed mobs.

Merrill Jensen, The New Nation: A History of the United States During the CONFEDERATION, I $781-1789$ xi (1950).

14 Baldwin v. G.A.F. Seelig, Inc., 294 U.S. 5 I I, 523 (1935).

I5 H.P. Hood \& Sons, Inc. v. Du Mond, 336 U.S. 525, 539 (1949). For an analysis, see Jack Michel, Comment, Hood v. Du Mond: A Study of the Supreme Court and the Ideology of Capitalism, I34 U. PA. L. Rev. 657, 683 (1986).

16 See, e.g., H.P. Hood \& Sons, 336 U.S. at 533 (citing Fiske in support of the proposition that the Confederation period was marked by commercial strife that threatened the peace of the Union); Independent Warehouses v. Scheele, 331 U.S. 70, 94 (1947) (Jackson, J., dissenting) (citing Fiske as a standard account of "[ $t$ ]he unedifying story of Colonial rivalry in preying upon commerce, which more than any one thing made our Federal Constitution a necessity"); see also Virginia v. West Virginia, 246 U.S. 565, 598-99 (1918), which cires Fiske in declaring:

That this absence of power to control the governmental attributes of the States, for the purpose of enforcing findings concerning disputes between them, gave rise to the most serious consequences, and brought the States to the very verge of physical struggle, and resulted in the shedding of blood and would, if it had not been for the adoption of the Constitution of the United States, it may be reasonably assumed, have rendered nugatory the great results of the Revolution, is known of all and will be found stated in the authoritative works on the history of the time.

17 JeNSEN, supra note 13, at xii.

I 8 Id. Even Andrew McLaughlin, who wrote that Fiske's "exceedingly interesting and 
charged that the standard account is simply not an accurate picture of the Confederation period. Jensen wrote that "[n]o idea is more firmly planted in American history than the idea that one of the most difficult problems during the Confederation was that of barriers to trade between state and state." ${ }^{19}$ Though some barriers existed, like those that New Jersey and Connecticut levied on goods brought in from neighboring colonies prior to the Confederation, Jensen admitted, they were not successful in building up local trade. ${ }^{20}$ During the Confederation period, Jensen wrote that the only example of interstate friction from trade barriers resulted from New York's taxation of goods coming from New Jersey and Connecticut, which resulted in New Jersey's taxing of New York's lighthouse at Sandy Hook. "This," Jensen sniffed, "is the teapot tempest which is so often cited as an example of interstate trade barriers during the Confederation." stated that most, if not all, states exempted from their duties and impost laws goods made or grown in the United States. ${ }^{22}$

Citing examples of reciprocity in a number of states, Jensen concluded that "the picture by the end of 1787 [was] not the conventional one of interstate trade barriers, but a novel one of reciprocity between state and state." ${ }^{23}$ Arguments to the contrary, he declared, mistake the contemporary complaints of disaffected nationalizers for historical fact.

There is ... little factual basis for the ancient tale repeated so faithfully by writers who follow in one another's footsteps without examining the evidence. The supporters of centralized power used the few discriminatory laws as an argument for a new government [i.e., the Constitution], but they

popular narrative" made no significant errors of fact and generally got the tenor of the times correct, qualified his praise with the remark that "as an authority the work is altogether without scientific standing, because it is little more than a remarkably skillful adaptation of a very few secondary authorities, showing almost no evidence of first-hand acquaintance with the sources." Andrew C. Mclaughlin, The Confederation and the Constitution i 783-i 789 , at 319-20 (1905).

19 JENSEN, supra note 13 , at 337 .

20 See id. at 338.

2 I Id. at 339.

22 See id. at 339 n.24 ("Like the other states,... Connecticut exempted goods produced or manufactured in the United States from import duties."); see also id. at 340:

The general rule was that all American goods were exempted from state imposts. American ships paid no higher tonnage duties in the ports of a state than did the shipowners of that state. Trade "barriers," contrary to the tradition, were the exception, rather than the rule. In fact, there were no trade barriers at all during the Confederation as compared with interstate barriers which have grown up in the twentieth century.

Whatever Jensen may have meant by his last sentence, unlike during the Confederation Period, effective weapons now exist with which to eliminate such barriers.

23 Id. at 342. 
ignored other laws which disproved their case, and so partisan argument in time became "history." ${ }^{24}$

In sum, Jensen argued that fears of commercial warfare among the states were ghost stories told by Federalists to scare fence-sitters into supporting the new Constitution and that, in fact, the Confederation period was one of relative prosperity. To the extent that individual state legislation caused problems, it was just because states were dealing inconsistently with foreign governments. ${ }^{25}$ The conventional wisdom that judged the Confederation a failure, Jensen argued, was in large part winner's history. ${ }^{26}$

Jensen's revisionist thesis was embraced and pursued by William Zornow, a historian who examined commercial statutes from I 775 to 1789 in five states and concluded in every case that states were not discriminating against their neighbors' commerce as charged, but rather had, by 1788 , moved toward a free trade regime. ${ }^{27}$ Like Jensen, Zornow concluded that the charges of discrimination leveled by nationalists were at best inaccurate, if not deliberate fabrications designed to ensure support for a more centralized government.

In the pages that follow, I will argue that Jensen simply missed instances of discrimination among states during the Confederation period and that Zornow often engaged in extremely strained readings of his evidence to fit it neatly within the revisionist thesis. Discrimination in either tonnage duties or in imposts was the policy of a number of important states in the years before the Constitution of $\mathbf{I} 787$, and this discrimination provoked fear that such commercial rivalries would persist and fester if the Articles of Confederation were not amended and power over interstate and foreign commerce centralized. Moreover, despite the fact that states often exempted products that were produced, manufactured, or grown in the United States, when states discriminated against ostensibly foreign goods imported in one state by American merchants and exported for sale to another state, it was the American merchant, not the foreign country, that felt the pinch. Though not discrimination against products from other states, this practice was no less discrimination against commerce from neighboring states.

$24 \mathrm{ld}$. at 339 .

25 Id. at $287-88,292$.

26 Id. at 245-46, 339-40.

27 See William Zornow, Geongia Tariff Policies, 1775 to 1789 , 38 GA. Hist. Q. 1 (1954) [herinafter Zornow, Geongia Tariff Policies]; William F. Zornow, Massachusetts Tariff Policies, 1775-1789, 90 Essex InST. Hist. Collections 194 (1954) [herinafter Zornow, Massachusetts Tariff Policies]; William F. Zornow, Newo York Tariff Policies, 1775-1789, 37 Proc. N.Y. ST. Hist. Ass'N 40 (1956) [hereinafter Zornow, New York Tariff Policies]; William F. Zornow, Tariff Policies in South Carolina, 1775-I 789, 56 S.C. Hist. MAG. 31 ( I955) [hereinafter Zornow, South Caroline Tariff Policies]; William F. Zornow, The Tariff Policies of Virginia, 1775-1789, 62 VA. MAG. Hist. \& BIOGRAPHY 306 (1954) [hereinafter Zornow, Vinginia Tariff Policies]. 


\section{The Confederation Economy and Its Regulation: An Overview}

\section{A. Postrear Economic Expansion and Contraction}

State economic regulation during the Revolution largely consisted of embargoes on the export of goods necessary for the war effort and bounties designed to encourage local production of those essentials that, because of the war, were no longer imported. ${ }^{28}$ Following the end of the Revolution, many states began to relax wartime restrictions and pass laws designed to raise revenue and stimulate commercial activity. ${ }^{29}$

The demand for goods was certainly present. ${ }^{30}$ The immediate aftermath of the war saw the U.S. economy expand. Demand for goods, especially English goods, ${ }^{31}$ led to rising prices. To supply this demand, American merchants took advantage of credit provided by English lenders to purchase these goods. ${ }^{32}$ Curtis Nettels noted that the U.S. purchased nearly $\$ 6$ million worth of goods during I 784 and I 785 , which resulted in price increases; between 1784 and 1786 , nearly $\& 8$ million worth of goods were purchased, three-fourths to four-fifths of which were purchased on credit. ${ }^{33}$

Two things occurred as a result: the flood of imported goods threatened the nascent domestic manufacturers that had grown up during the war, and specie flowed out of the country to merchants' English creditors. ${ }^{34}$

28 See Albert Anthony Giesecke, American Commercial Legislation Before 1789 , at 123 (1970 ed.) (1910) ("The outbreak of the Revolution severed the political and commercial relations with England, which had existed for more than a century. For the next six or seven years the vicissitudes of war gave little time or opportunity for trade, except in munitions of war and the necessaries of life.") (footnote omitted); id. at 124, I25 (noting that "the main emphasis [of wartime commercial regulation] was placed upon embargoes" and that "trade was practically suspended" during the Revolution); John J. MCCusker \& Russell R. MENARD, The ECONOMY OF British AMERICA, I607-1 789, at 363 (1985) (describing, as a consequence of the War for Independence, "a diversion of resources into the indigenous production of goods and services that had previously been purchased abroad"); Cathy D. Matson \& PETER S. ONuF, A Union of Interests: Political and Economic Thought in Revolutionary America 38 (1990) (describing the pattern of state economic regulation between 1778 and $\mathrm{I} 779$ as consisting of restrictions on imports and exports, limitation on profits, and embargoes).

29 Curtis P. Netrels, The Emergence of a National Economy, i 775-1815, at 46 (1962) ("War-born shortages of goods quickly brought about a revival of the import trade.").

$30 \mathrm{Id}$. at 45 (noting that by 1783 "states... found themselves in urgent need of manufactured goods"); see also McCuSKeR \& MENARD, supra note 28, at 277 ("The most significant aspect of the consumption of goods and services in the colonial economy was probably the increase in demand over time.").

31 NeTtEls, supra note 29, at 46 (discussing merchants' and consumers' preference for English, as opposed to French goods).

32 Id. at 47 (noting the importance of the willingness of British lenders to extend credit to American merchants).

33 Id. at $47-49$.

$34 I d$. at 49 (discussing the outflow of hard currency resulting from the trade imbalance); Matson \& ONUF, supra note 28, at 39 (noting that rumors of peace with England brought forth 
By 1784 this capital flight combined with a glut of goods, restrictions the English placed on American merchants' access to overseas markets, ${ }^{35}$ and depressed prices, ${ }^{36}$ had plunged the new nation into its first economic depression. ${ }^{37}$ According to two economic historians, "something 'truly disastrous' happened to the American economy between 1775 and $1790 . "{ }^{38}$ The performance of the economy during that period, they estimate, "fell by 46 percent." ${ }^{39}$ To offer a modern comparison, the gross national product during the Great Depression fell by forty-eight percent. ${ }^{40}$

\section{B. State Responses to Economic Crisis}

During the Confederation era, state commercial regulation generally took one or more of the following forms: (I) export embargoes imposed on scarce goods; (2) impost duties levied on imports; (3) tonnage charges imposed on cargo ships; and (4) export duties imposed on outgoing goods. Embargoes were common during the war both to preserve scarce commodities for home consumption as well as to keep valuable stores from falling into British hands if the importing state was overrun. For the most part, embargoes ceased with the end of the war with Britain.

Imposts and tonnage charges, imposed by nearly every state once the war ended and commerce resumed, could serve several functions. First, they could serve to raise revenue for the state. If the state had a busy port, the revenue from such measures could spare the population direct taxes on property or goods. Second, they could protect domestic industry. Many states raised duties on "luxury" goods, commonly British goods, in retaliation for the closing of various colonial ports to the ships of the newly independent United States.

States also imposed tonnage duties, measured by the carrying capacity of a ship's hold, on foreign shipping. With a few exceptions, export duties were not widely used in the several states, though many states did impose inspection fees designed to guarantee the quality and preserve the reputation of products emerging from the state. The most frequent forms of commercial regulation, and the most frequent sources of friction among the

an influx of goods and an outflow of currency).

35 See McCusker \& Menard, supra note 28 , at 370 ("[I]n the 1780 os both the agricultural and commercial sector experienced some problems, stemming largely from the closing of overseas markets for the goods produced.").

36 See NetTels, supra note 29, at 62.

37 Nettels notes that as early as 1783 a glut of English goods in New York caused prices to fall. See id. at 60. Richard Morris pegs the year of the first depression as i 784. Richard B. MORRIS, The Forging OF THE UNION, I 78 I-1 789, at 130 (1987).

38 MCCuSKER \& MENARD, supra note 28 , at 373 .

39 Id. at 374 .

$40 \mathrm{Id}$. 
several states in the Confederation period, were the impost duties imposed on goods coming into the state and the tonnage duties imposed on ships seeking to offload cargo at state ports.

In the words of one historian, "[p]eace brought with it the necessity of providing revenue to meet the current needs of government" and to pay off war debts. ${ }^{41}$ Economic difficulties hampered these efforts. ${ }^{42}$ In response, states began enacting protective tariffs seeking to raise revenue, curb imports, stop outflows of hard currency, and protect domestic manufacturers. ${ }^{43}$ The tariffs usually targeted (I) foreign "luxuries," (2) goods that could be supplied by state industries, (3) "useful" things not produced locally in sufficient quantities, like coaches, and (4) foreign liquor. ${ }^{44}$ The result was a confusing and conflicting skein of commercial regulations that lacked any coordination-one historian wrote that "occasional instances of harmony" were the result of "accident" not "design" terstate conflict. ${ }^{46}$

During this period, according to one count, six states passed imposts, nine states discriminated against British goods, seven states imposed duties on British ship entrances and British commodities, and three states forbade export of American goods in British ships. ${ }^{47}$ Nationalists began to express

41 GIESECKE, supra note 28, at 126.

42 MCCuSKER \& MENARD, supra note 28, at 372 (noting inadequacy of revenue measures during the 1780 ).

43 MORRIS, supra note 37 , at 148 ("To secure revenue, prevent dumping of foreign goods, and protect emerging native industries, a majority of the thirteen states levied tariffs on imports, a source of income they denied to Congress."); see also id. (listing "hardware, woolen and cotton cloth, hats, and sailcloths" among industries "that enjoyed such protection"); NetTELs, supra note 29, at 69 ("Several of the states attempted to overcome the hardships of the 1780 os by enacting defensive or remedial laws" like protective tariffs; describing 1785 meetings of "manufacturers, artisans, and mechanics of New York, Philadelphia, and Boston" at which they demanded duties designed to curb imports, protect industries and stop the outflow of money) (footnote omitted); see also Willard Clark Fisher, American Trade Regulations before 1789, 3 PAPERS OF THE Am. Hist. Ass'N 223, 234 ( 1888 ) (listing imposts, tariffs, and tonnage duties as included within the class of "those which bear upon imports" passed by states).

44 NetTels, supra note 29, at 69-70.

45 Fisher, supra note 43 , at 235 ; $i d$. at 248 ("It is impossible briefly to summarize the whole matter of colonial and state trade legislation, unless it be by the one word 'confusion."').

46 Id. ("Not only ... were the regulations very numerous, but they were without unity and harmony.").

47 Cathy Matson, The Revolution, the Constitution, and the Nero Nation, in I The Cambridge Economic History of the United States: The Colonial Era 363, 379 (Stanley L. Engerman \& Robert E. Gallman, eds., 1996) [hereinafter Matson, The Revolution, the Constitution, and the New Nation]; see also Netrels, supra note 29, at 72 ("The lawmakers of six states... put[] special taxes on goods imported in British ships."); see also MaTson \& ONuf, supra note 28, at 4I, 45 (noting that after failed attempts to secure congressional power to regulate commerce "[s]ix states enacted ... imposts" and that "[i]n 1784 and 1785 , nine states added steeper duties on British goods entering their ports"); Fisher, supra note 43, at 245 (describing "[o]ne particular form of discrimination" that depended upon "the nationality of the carrying bot- 
concern that "the states, acting on their own, were more likely to be drawn into conflicts with one another than to improve their commercial situations." ${ }^{8}$ This began to occur as "[s]tates with major port cities, especially New York and Massachusetts, took advantage of their superior position in international commerce and in regional markets to pass discriminatory duties against neighboring states' traffic at their ports." ${ }^{49}$ As Curtis Nettels noted, "[i]nherent in state tariff laws was the danger that some states might tax the exports of a neighbor, thereby limiting its market."

Not surprisingly, though the aim of such state laws was "foreign goods," the line between foreign and domestic goods became blurred once these goods were imported by American merchants and traveled among states. ${ }^{51}$ Friction between states arose as these protective laws raised costs of importing, shipping, and selling goods for American merchants. ${ }^{52}$ Importers responded by shifting goods from ports in states enacting such laws to states that decided to make their ports duty-free and then by importing those goods overland into taxing states. ${ }^{53}$ This, in turn, encouraged laws

tom"); GIESECKE, supra note 28 , at 128 (noting that "[d]iscrimination by higher duties on goods imported in British vessels was most prominent in the New England states (except Connecticut ... and New York.")).

For a rather dramatic description of the situation, see I GEORge Bancroft, History of the Formation of the Constitution of the United States of America i 86 (New York, D. Appleton and Company 1882):

[E]xcessive importations at low prices crushed domestic manufactures; trade with the British West Indies was obstructed; neither rice, tobacco, pitch, turpentine, nor ships could be remitted as heretofore.... The Americans had chosen to be aliens to England; they could not complain of being taxed like aliens, but they awoke to demand powers of retaliation.

48 Matson \& Onuf, supra note 28, at 70.

49 Matson, The Revolution, the Constitution, and the Nero Nation, supra note 47 , at 380.

50 NeTtELS, supra note 29, at 71.

51 See GieseCKE, supra note 28, at 134:

The other tariff feature which necessarily developed out of the conditions of the time was the discrimination or retaliation against commodities imported from neighboring states.... [W]ith each state sovereign, there was scarcely any redress, for few agreements existed which tended to check discrimination.

52 See JENSEN, supra note 13 , at 287 (noting that protective tariffs "show the widespread interest in developing manufactures" while noting that the "passage of such legislation involved sharp battles with the American importers"); id. at 292 (describing one such conflict in Massachusetts in 1785 ).

53 See Matson, The Revolution, the Constitution, and the New Nation, supra note 47, at 380-8 I (noting that in response to New York's discriminatory tariff policies, states like New Jersey and Delaware responded with free trade measures and "discouraged the flow of raw materials to manufacturers in states which assessed heavy taxes on 'foreign'-that is, other states' commodities"); NetTels, supra note 29, at 73 (discussing how free trade policies of Connecticut, New Jersey, Delaware, South Carolina, and Georgia hurt their manufacturing neighbors); see also Marson \& ONUF, supra note 28, at 72-73. 
aimed at goods imported from those states with duty-free ports, or those goods originally imported in foreign bottoms, and the like. ${ }^{54}$ For example, New Hampshire, Massachusetts, and Rhode Island barred British ships from loading U.S. products in their ports, which simply sent those ships to ports in other states. ${ }^{55}$ In early 1785 , New York imposed a five-percent tax on commodities imported from other states for sale to New Yorkers in response to efforts to avoid its imposts and tariffs on imported goods. ${ }^{56}$ That these laws, ostensibly directed at the British, often hit other Americans is an important point to keep in mind when evaluating whether the exemption of out-of-state goods and manufacturers from state imposts and duties meant that there was no discrimination against out-of-state commerce, as the revisionists maintained.

States with fewer geographical advantages resented the bite that port states took from commerce that had to pass through those ports before arriving in the hinterlands. ${ }^{57}$ This friction sometimes escalated, resulting in imposts and tariffs specifically targeting goods coming from a particular state. "By the mid- 1780 s, ... it was becoming clear to Americans concerned about international and interstate developments that distinct state policies often pitted some groups of Americans against others." ${ }^{58}$ According to many historians, this competition sometimes resulted in overt discrimination by one state against goods produced in or re-exported from a neighboring state. ${ }^{59}$

54 For example, in 1785 , New York imposed double duties on all goods imported in British ships. It is said that this act "was the cause of considerable trouble and discrimination by neighboring states" because it presumed that goods imported from Rhode Island, Connecticuc, New Jersey or Pennsylvania had been imported in British ships, unless it could be proven otherwise. GIESECKE, supra note 28, at 128-29, 129 n.24.

55 NetTELs, supra note 29, at 72.

56 Matson, The Revolution, the Constitution, and the Nero Nation, supra note 47, at 380; see also NetTEls, supra note 29, at 72 ("Connecticut taxed foreign goods from Massachusetts, and New York in 1787 put special duties on foreign goods imported by American vessels from Connecticut and New Jersey.") (footnote omitted).

57 See, e.g., Jack N. Rakove, The Beginnings of National Politics: An Interpretive History of the Continental Congress 34 I (1979) (noting that because New Jersey lacked a port, it contributed to New York's state impost).

58 Matson, The Revolution, the Constitution, and the New Nation, supra note 47, at 377.

59 See, e.g., GeISECKE, supra note 28, at 124-25, 126-27, 134-35, 139-40, I48; MATSON \& ONUF, supra note 28, at 72-75; MORRIs, supra note 37, at 148-49; NeTTELS, supra note 29, at 69-73; Matson, The Revolution, the Constitution, and the New Nation, supra note 47, at 379-80. 


\section{Contemporary Comment on Confederation-Era State Commercial Regulation}

Although "[n]ationalists did not represent a majority of Americans between 1781 and $1784, \ldots$ their numbers grew." "[T] merce" and "the centrifugal, contentious economic interests rising among the states" at the time "dampened ... postwar enthusiasm and reoriented public and private views toward the Nationalists," ${ }^{61}$ who warned that discrimination against the commerce of neighboring states weakened the economies of all states, and that the "enmity of 'sovereign' states made Americans foreigners to one another," threatening both the economic selfsufficiency of the new states as well as the Union as a whole. ${ }^{62}$ The inability of the Continental Congress to harmonize the commercial policies of the several states, and its failure to convince states to part with that much of their sovereignty as would permit Congress to regulate commerce and raise revenue of its own, convinced many fence-sitters that the problem lay with the Articles of Confederation and encouraged moderate nationalists, like James Madison, that the survival of the union necessitated substantial changes in the constitutional regime. ${ }^{63}$

The letters and writings of prominent advocates of constitutional reform, like Alexander Hamilton ${ }^{64}$ and James Madison, constantly comment-

6o Matson, The Revolution, the Constitution, and the Nero Nation, supra note 47, at 372; see also Netrels, supra note 29, at 60 ("The economic conditions existing in the Union in the I 780 's proved to be extremely important. They formed an essential part of the background of the making of the federal Constitution.").

6I Matson, The Revolution, the Constitution, and the New Nation, supra note 47, at 373.

62 Marson \& ONuf, supra note 28, at 51;

"Continentially-minded" nationalists became convinced that jealousies between states with strong ports and states with weak ports, or between northern and southern states, would negate hopes for self-sufficiency both within and among the states. By erecting their own barriers to British commerce, the American states perpetuated conflicts among themselves....

Id. at 74 .

63 Seeid. at 67 ("Nationalists were convinced that congressional impasse over commercial policy was a function of the fundamental flaws in the organization of the union under the Articles of Confederation.").

64 Even before the Revolution ended, worries were expressed about the lack of uniformity in the laws of the States. In $\mathbf{1 7 8 0}$, Alexander Hamilton wrote to his friend James Duane that:

[t]he fundamental defect [in the Confederation] is a want of power in Congress.... The idea of an uncontrollable sovereignty in each state, over its internal police, will defeat the other powers given to Congress, and make our union feeble and precarious. There are instances without number, where acts necessary for the general good, and which rise out of the powers given to Congress must interfere with the internal police of the states, and there are as many instances in which particular states 
ed upon the inability of the Confederation government to stop commercial predation among the states. ${ }^{65}$ Expressions of frustration at the states' unwillingness to grant sufficient power to the Confederation Congress to ensure its financial independence, and at the states' commercial policies regarding both foreign and interstate commerce, abound in the writings of the future collaborators. Madison and others eventually concluded that only a general grant of power to Congress, coupled with explicit restrictions on the states, would secure the financial and commercial future of the United States. These two men were neither mindless nationalizers, nor were they "angry politicians and soldiers" who "were seldom easy when in office and who prophesied doom when their opponents won elections," as Merrill Jensen characterized critics of the Confederation.

\section{A. Failed Efforts to Reform the Articles of Confederation}

In I 78 I Congress recommended to the states that it be given the power to impose a five-percent impost on imports. All states but Rhode Island approved ${ }^{67} ;$ thereafter, Virginia rescinded its initial ratification of the impost, effectively dooming it, as other states followed Virginia's lead. ${ }^{69}$ Undaunted by the failure of the impost of $178 \mathrm{I}$, Congress proposed that it be given the power, for a period of twenty-five years, to levy a duty on imported goods "with the express understanding that the income should be used only for the discharge of principal and interest of the debt." ${ }^{, 70}$ But the states resisted

by arrangements of internal police can effectually though indirectly counteract the arrangements of Congress....

Letter from Alexander Hamilton to James Duane (Sept. 3, 1780), in 2 The PApers of Alexander Hamilton 401-02 (Harold C. Syrett et al. eds., 196I-68). Congress, Hamilton argued, must have "powers competent to the public exigencies," regardless of any effects on state sovereignty. $1 d$. at 407 .

65 See infra Part III.B.

66 JENSEN, supra note 13 , at 85 .

67 See, e.g., Act of May, 1782 , Acts and Laws Made and Passed by the Governor and Company of the State of Connecticut 599 (1782) (authorizing Congress to impose fivepercent ad valorem impost on imports "from any Port, Island or Plantation not within any of the United States") [hereinafter Connecticut Acts]; Act of June 2, $178 \mathrm{I}$, Ch. XXIII, Acts of the General Assembly of the State of New Jersey 75 (1781) [hereinafter New Jersey AcTs].

68 See, e.g., Act of May, 1781, Ch. II, Acts Passed at a General Assembly of the CoMmonwealth of Virginia 4 ( $178 \mathrm{I}$ ) (suspended in November, I78I) [hereinafter Virginia Acts], repealed by Act of May, i 782, Ch. XLII, VIRGINIA Acts, supra, at 4.

69 See, e.g., Act of Feb. 26, I782, Ch. VIII, Acts Passed at a General Assembly of the State of South Carolina 4 (1782) (impost approval) [hereinafter South Carolina Acts], repealed by Act of March 16, 1783, South CAROLINA Acts, supra, at 57 (citing as the reason for repeal the refusal of Rhode Island and the repeal of Virginia, both of which made the previous act "repugnant to the commercial interest of this State").

70 McLaughlin, supra note 18, at 79 (footnotes omitted); see also Max Farrand, The 
this measure, too; many were unwilling to act without assurances that the others would not undercut them. ${ }^{71}$ A 1784 proposal asked that Congress be given the power to "meet the restrictions of England [on American imports] with similar restrictions," including

the right for fifteen years to pass a navigation act, and thus prohibit the importation or exportation of any goods in ships belonging to or navigated by subjects of any power with whom the United States should not have a treaty of commerce. Authority was also asked to prohibit... the subjects of any foreign state, unless authorized by treaty, from bringing into the United States merchandise which was not the product or manufacture of the dominions of their sovereign. ${ }^{72}$

Historian Andrew McLaughlin reported that "the request of Congress for power to pass a navigation act met with a cold reception in the states," which "acted ... as if some foreign power rather than their own representatives were asking for authority." Suspicion of abetting the growth of congressional power and thereby reducing their own power, as well as states' "You first, Alphonse" aversion to unilateral action, put them in a bind. In McLaughlin's words:

Refusing to grant power to Congress, the states could not themselves act in unison. Some of them had passed their own acts in regulation of commerce, but such independent measures were ineffectual.... In fact, their laws were

Framing of the Constitution of the United States 5 (1913) (describing efforts of Congress to wrest commercial power from the states).

7 I See, e.g., Act of June I 1, 1783 , Ch. XXVII, New Jersey Acts 54 (1783) (repealing 1781 Act, but allowing Congress to lay impost on imported rum, liquor, wine, tea, pepper, sugar, coffee, cocoa, and other goods for twenty-five years; until such time as the necessary number of states approve, "all the Ports in this State be...f free and open for the Importation and Exportation of any Goods ... clear of all Duties, Customs or Impositions.").

In spite of all efforts and though the need was sore, the recommendations were not followed by the states. Each watched the other warily, fearing that its neighbor might win some commercial advantage. Three years after the measure was laid before the states for adoption, seven statesNew Hampshire, Massachusetrs, Connecticut, New Jersey, Virginia, North Carolina, and South Carolina-had granted the impost in such a manner and under such restrictions that if the other states had made similar grants the plan of the impost might immediately have gone into operation. But Pennsylvania and Delaware had consented to the measure with the proviso that it should not go into effect until all of the states passed laws in conformity with the whole revenue system proposed. Only two of the states-Delaware and North Carolina-acceded to the system in all its parts; and four-Rhode Island, New York, Maryland, and Georgia-did not decide in favor of any part of the system.

MCLaughlin, supra note 18 , at 79-80.

72 McLaughlin, supra note 18 , at 84 (footnote omitted).

73 Id. at 85 (footnotes omitted). 
confusing and conflicting. There seemed at times to be little desire to reach a common basis for the regulation of commerce or the levying of imposts. Too often legislation was shaped rather by jealousy and the hope to win trade away from a neighboring state than by principles of wise policy or foresight. $^{74}$

In a final, futile attempt to bring some order to the commercial scene, Congress requested the power to levy imposts the year before the Annapolis Convention. Though some states acceded to its request, ${ }^{75}$ more than enough states attached leaden conditions, designed to sink the plan, to ensure its failure. ${ }^{76} \mathrm{McLaughlin}$ concluded that "[e]xperience, it is plain, had before 1786 taught the necessity of bestowing on some central authority the power to regulate commerce and the power to obtain revenue without merely begging for it."77

\section{B. State Commercial Policy and the Growing Sentiment for Systemic Reform}

Writing to James Madison in 1782 , Edmund Randolph expressed frustration at the inability of Congress to pass generally applicable laws forbidding trade with areas of the country occupied by the British, and the lack of comparable state laws on the subject. ${ }^{78}$ Frustration grew with the

74 Id. at 86 (footnotes omitted). Professor Farrand provided a similar characterization: Pending a grant of power to congress over matters of commerce, the states acted individually. A uniform policy was necessary, and while a pretense was made of acting in unison to achieve a much desired end, it is evident that selfish motives frequently dictated what was done. Any state which enjoyed superior conditions to a neighboring state was only too apt to take advantage of that fact.... Interference with the arteries of commerce was cutting off the very life-blood of the nation, and something had to be done. The articles of confederation provided no remedy....

FARrand, supra note 70 , at 7 .

75 See, e.g., Act of Jan. 2, 1784, New Hampshire Acts, at 307; Act of June 23, 1785, New HAMPSHIRE ACTS, at 361 (vesting Congress with authority "to make and enter into such general ordinances and treaties, for the due regulation of the Trade and Commerce of the United States, as they may judge best calculated to promote the weal and prosperity thereof" with all revenue derived to be "appropriated to the sole use of discharging the public debt"); Act of Dec. 28, 1786, New HAMPSHIRE ACTs, at 425 (same; combining Acts of 1784 and 1785 ); Act of March 21, I 784, South Carolina ACTs, at 19 (authorizing the imposition of certain duties on rum, liquor, wines, tea, pepper, sugar, cocoa, and coffee).

76 See, e.g., Act of Dec. 23,1784 , Ch. LXXXV, New Jersey Acts, at I 76-77 (authorizing imposition of duties specified in previous Act "as soon as eleven States of the Union shall adopt or accede to the Measure"); Act of March 21 , 1784 , South Carolina Acts, at 21 , repealed by Act of March I1, 1786, SouTh CAROLINA ACTs, at I6 (expanding the grant of power to include West Indies and "all other external or foreign trade of the said States" for fifteen years upon the consent of nine of the thirteen states).

77 McLaughlin, supra note 18 , at 173.

78 Letter from Edmund Randolph to James Madison (Aug. 16, 1782), in 5 ThE PAPERS OF 
news that Rhode Island had refused its assent to the five-percent impost requested by Congress. Madison wrote to Randolph of Rhode Island's "obstinacy," which was "a blow to our credit abroad as well as our future credit at home." 79 Madison commented that Rhode Island's intransigence was due in part to the "limited manner in which other states have acceded to the impost from which she infers a latent repugnance to the measure."80 Edmund Pendleton proposed repassing the impost and levying a duty on all goods imported into Rhode Island, then exported to other states, to prevent a windfall to her ports.

The states' unwillingness to cede control over the levying of imposts and duties was in part due to the fact that such measures were a way to raise revenue without directly taxing their citizens. In notes Madison made while in Congress in 1783 , he assayed the states' interest in what he called "a general revenue" for Congress. According to his notes, much state support hinged on the expectation that the general revenue would insulate states from the predations of their neighbors. ${ }^{83}$

In Madison's notes, Connecticut, ${ }^{84}$ New York, ${ }^{85}$ New Jersey, ${ }^{86}$ and North Carolina ${ }^{87}$ were all favorably disposed to a congressional power to collect a general revenue on commerce as a way to guard against separate taxation

JAmes Madison 59 (William T. Hutchinson et al. eds., I967) [hereinafter Madison PAPERs].

79 Letter from James Madison to Edmund Randolph (Nov. 26, 1782), in MADISON PAPERS, supra note 78, at 33I (footnote omitted).

$80 \mathrm{Id}$.

81 Letter from Edmund Pendleton to James Madison (Dec. 9, 1782), in MADison PAPERS, supra note 78 , at 383 . Pendleton wrote of his idea that

I se[e] no objection to this method, unless it be supposed that this duty would be considered such a [c]log upon trade as to give Rhode Island an unreasonable advantage in commerce by throwing the imports into that State-an objection w[hi]ch ... does not appear of much consequence, when applied to a single [state], especially if provision be made for Subjecting to the Duty all goods imported there, \& afterwards brought

Id. into another State....

826 Madison Papers, supra note 78, at 290.

83 See id.

84 See id. at 291 ("Connecticut is interested in a general revenue as tending to protect her from separate taxation by N. York \& Rhode Island....").

85 See id. ("N. York is exceedingly attached to a general revenue as tending to support the confederacy and prevent future contests among the States.").

86 See id. ("N. Jersey is interested as a smaller State in a general revenue as tendg [sic] to support the confederacy, and to prevent future contests and to guard her commerce agst. the separate taxation of Pennsylvania \& N.Y.").

87 See id. at 292 (supporting general revenue to protect against taxation by South Carolina and Virginia). 
by neighboring states. Rhode Island, ${ }^{88}$ Pennsylvania, ${ }^{89}$ Virginia, ${ }^{90}$ and South Carolina, ${ }^{91}$ which profited from taxing the commerce of neighboring states, opposed it. Despite the recognition that the common interest of the states lie in fostering free trade, few of them were willing to take steps unilaterally; the momentum continued away from the five-percent impost into 1783 , with more rescissions threatened. ${ }^{92}$

Thus, as early as i 783 , Madison worried over the commercial policies of the states. He wrote Jefferson that the merchants of Philadelphia and Baltimore were so heavily taxing the imports and exports of Virginia that it amounted to "a tribute which if paid into the treasury of [Virginia] would yield a surplus above all its wants." national situation after he left the Confederation Congress and assumed a seat in the Virginia House of Delegates in $1784 .{ }^{94}$ During this period, Madison became convinced that the Articles of Confederation needed revision, and concluded (albeit with reservations) that a national convention was the correct forum for the presentation and debate of such amendments. Commercial matters were foremost in his mind, and among commercial matters, the situation among the states themselves figured prominently in his correspondence and his plans to remedy the imporence of the Confederation Congress.

In a letter to Madison on December 14, I784, James Monroe reported that Connecticut had "laid a duty of 5 pr. centm. upon all goods imported from a neighb[o]ring State," which was calculated "to affect[] R[hode] Island very sensibly." 95 A letter from Monroe in July 1785 described efforts to amend the Articles of Confederation in Congress. One proposal would have "invest[ed] Congress with power to regulate trade externally $\&$ in-

88 See id. at 291 ("Rhode Island as a weak State is interested in a general revenue as tending to support the confederacy and prevent future contentions, but against it as tending to deprive Her of the advantage afforded by her situation of taxing the commerce of the contiguous States....").

89 See id. ("As far as a general impost on trade would restrain [Pennsylvania] from taxing the trade of $\mathrm{N}$. Jersey it would be against her interest.").

90 See id. (commenting on Virginia's desire to tax the commerce of North Carolina).

91 See id. at 292 (commenting on South Carolina's similar desire to tax the commerce of North Carolina).

92 See, e.g., Letter from James Madison to Edmund Randolph (Apr. I, 1783), in 6 MADISON PAPERS, supra note 78, at 429-30 (reporting "alarming" news of repeal of five-percent impost by lower house of Massachusetts and South Carolina). But see id. at 43 I n.3 (explaining that neither state ended up rescinding approval at that time).

93 Letter from James Madison to Thomas Jefferson (Dec. 10, 1783), in 7 MaDison PAPERS, supra note 78 , at 401 ; see also id. at 403 n. 10.

94 See 8 Madison Papers, supra note 78 , at xix-xxi.

95 Letter from James Monroe to James Madison (Dec. 14, 1784), in 8 Madison PaPers, supra note 78 , at 184 . 
ternally." 96 The arguments in favor of such a power were based largely on the benefits of uniformity. If the states continued to pursue separate commercial policies with regard to both foreign nations and their neighboring states, "they will become instrumental in their hands to impede \& defeat those of each other." 97 By acting "against each other," Monroe wrote, the states "establish'd deep-rooted jealousies \& enmities between them" and "such a course tended to throw them apart $\&$ weaken the present rights of the confederacy." 98

Madison set forth his views in a lengthy response to Monroe. While confessing his own preference for free trade, Madison allowed that the power to regulate commerce, "[i]f it be necessary ... at all" must surely be lodged in Congress "where trade can be regulated with effect." power "can never be so regulated by the States acting in their separate capacities," he continued, dryly noting that "experience has confirmed what reason foresaw." ${ }^{100}$ Madison ruefully noted in a letter to Jefferson that "Congress have kept the Vessel from sinking, but it has been by standing constantly at the pump, not by stopping the leaks which have endangered her." ${ }^{\prime 01}$ One of the "leaks" was the lack in Congress of an adequate power over trade. ${ }^{102}$ Madison noted that even the unilateral actions of some states, like Pennsylvania's imposition of a levy on imports from Great Britain, "could scarcely be enforced against the smuggler, if N. Jersey, Delaware \& Maryland were to co-operate with her." ${ }^{103}$

Madison reluctantly advocated the calling of the Annapolis Convention as a way to remedy the commercial defects of the Articles. ${ }^{104}$ His support for it came only after his "unwavering determination to strike the problem at its root" ${ }^{105}$ failed to stop the leaks in the Articles. His determination is evident in a set of resolutions Madison drafted in November 1785 . Though

96 Letter from James Monroe to James Madison (July 26, 1785 ), in 8 MADison Papers, supra note 78 , at 329 .

$97 \mathrm{Id}$. at 330 .

$98 \mathrm{Id}$.

99 Letter from James Madison to James Monroe (Aug. 7, 1785), in 8 Madison PAPERS, supra note 78 , at 333 .

$100 \mathrm{Id}$.

10I Letter from James Madison to Thomas Jefferson (Oct. 3, 1785), in 8 Madison Papers, supra note 78 , at 373 .

102 Id. at 374.

I03 Id. at 375 .

104 See Debates and Resolutions Related to the Regulation of Commerce by Congress, Including a Call for a Convention at Annapolis, November I 785-January I 786, in 8 MADIson PAPERS, supra note 78, at 406 (editorial note) (" $[T]$ he documents and letters emanating from the October 1785 session of the Virginia General Assembly show that Madison was consistently lukewarm to the convention approach as a remedy for the ills of national government.").

I05 Id. at 407. 
entitled "Draft of Resolutions on Foreign Trade," ${ }^{106}$ it contained references to difficulties arising from competition over interstate commerce as well. "[T]he unrestrained exercise of the powers possessed by each State over its own commerce," the second resolve read, "may be productive of discord among the parties to the Union; and... Congs. ought to be vested with authority to regulate the same in certain cases." ${ }^{107}$ The fourth resolve stated that

no State ought to be at liberty to impose duties on any goods ware or merchandizes imported by land or water from any other State, but each State ought to be free to prohibit altogether the importation from any other State, of any particular species or description of goods wares or merchandizes, which are at the same time prohibited to be imported from all other places whatsoever. ${ }^{108}$

This section was preserved in the final resolution passed by the Virginia House of Delegates on November $14,1785 .{ }^{109}$ The resolution was a firm statment of the sentiment expressed by George Washington in a reply to Madison's resolutions. Washington wrote that

[ $t$ ]he proposition in my opinion is so self evident that I confess I am at a loss to discover wherein lyes [sic] the weight of the objection to the measure. We are either a United people, or we are not. If the former, let us, in all matters of general concern act as a nation, which have national objects to promote, and a national character to support. If we are not, let us no longer act a farce by pretending to it. ${ }^{10}$

In notes composed by Madison in "a hasty preparation for the House debates on 30 Nov. and I Dec." tions were "necessary to prevent animosity ... \& smuggling," listing out to the side the names of Massachusetts and Connecticut; New York and New Jersey; and Pennsylvania.'

During the same legislative session, Madison co-sponsored a resolution calling for a federal convention for the purpose of proposing amend-

106 Id. at 409 (emphasis added).

$107 \mathrm{ld}$.

108 Id. at 409-10. (emphasis added). The latter clause "must have been written with the slave trade in mind;" Virginia had prohibited the importation of slaves since 1778 . Id. at 410 n.2.

109 See Resolution Calling for the Regulation of Commerce by Congress (Nov. 14, 1785 ), reprinted in 8 MADISON PAPERS, supra note 78, at 413-14. Note that the title of the resolution was changed, and now reflected a general concern with "Commerce," rather than a specific concern with "Foreign Trade."

I 10 Letter from George Washington to James Madison (Nov. 30, 1785), in 8 Madison PAPERS, supra note 78 , at 429.

11 I See Notes for Debate on Commercial Regulation by Congress (Nov. 30-Dec. I, I785), in 8 MADISON PAPERS, supra note 78, at $432 \mathrm{n}$.

I 2 Id. at 431 . 
ments to the articles dealing with the regulation of commerce. In a letter to Jefferson, who was in Paris, Madison wrote that "[t]he necessity of harmony in the comercial [sic] regulations of the states has been rendered every day more apparent," and he further noted that efforts aimed at the trade of Great Britain "instead of succeeding have in every instance recoiled more or less on the states which ventured on the trial." "'3 When Madison described the resolutions passed by the House of Delegates, interstate commercial discrimination was prominently mentioned as a source of friction among states, one to be remedied by granting a power of commerce coupled with concomitant restrictions on the States:

[The resolutions'] object was to give Congs. such direct power only as would not alarm, but to limit that of the States in such manner as wd. indirectly require a conformity to the plans of Congs. The renunciation of the right of laying duties on imports from other States, would amount to a prohibition of duties on imports from foreign Countries, unless similar duties existed in other States. This idea was favored by the discord produced between several States by rival and adverse regulations. The evil had proceeded so far between Connecticut \& Massts. that the former laid heavier duties on imports from the latter than from $G$. B. of which the latter sent a letter of complaint to the Executive here and I suppose to the other Executives. Without some such self-denying compact it will, I conceive be impossible to preserve harmony among the contiguous States. ${ }^{14}$

On the same day, Madison wrote to Monroe complaining of the failure of the Virginia legislature to revise the State's commercial statutes, with the result that the old statute, which Madison described as "[d]efective ...particularly in putting Citizens of other States on the footing of foreigners" was left in place. ${ }^{115}$ In March 1786, Madison again complained to Jefferson that the states were, through diverse commercial policies, frustrating sister states that had retaliated against Great Britain for the closing of its ports in the West Indies to American ships. ${ }^{116}$ In August of the same year, Madison complained of paper money measures in the States, claiming that "it is pro-

1 I 3 Letter from James Madison to Thomas Jefferson (Jan. 22, 1786), in 8 MADIson Papers, supra note 78 , at 476 .

114 Id. (emphasis added).

115 Letter from James Madison to James Monroe (Jan. 22, i786), in 8 Madison PaPers, supra note 78 , at 483 (emphasis added).

I 6 See Letter from James Madison to Thomas Jefferson (Mar. 18, 1 786), in 8 Madison PAPERS, supra note 78, at 502 ("The States are every day giving proofs that separate regulations are more likely to set them by the ears, than to attain the common object. When Massts. set on foot a retaliation of the policy of G[rear] B[ritain] Connecticut declared her ports free. N. Jersey served N. York in the same way. And Delaware I am told has lately followed the example in opposition to the commercial plans of Penna. A miscarriage of this attempt to unite the States in some effectual plan [i.e., the Annapolis Convention] will have another effect of a serious nature. It will dissipate every prospect of drawing a steady revenue from our imposts..."). 
ducing the same warfare $\&$ retaliation among the States as were produced by the State regulations of commerce."17

\section{To the Philadelphia Convention}

In September I 786 , Madison attended the abortive convention ar Annapolis, Maryland. Initially lukewarm to the idea of a convention, Madison's affinity for a general convention of the states as a way to achieve a solution to the seemingly intractable commercial controversies steadily increased. ${ }^{118}$ There was some opinion that Madison was pursuing too narrow an agenda in Annapolis. Rufus King, congressman from New England, wrote the business partner of an Annapolis delegate that to be effective Congress needed much more than plenary power over commerce. Presciently, King wrote that, in any event, without an effective judicial remedy, any powers granted could not be effectively enforced. "

Though the convention was stillborn, evidence suggests that Madison and others had intended the convention to take up not only the problem of diverse state actions stymieing effective regulation of foreign commerce, but also the use of regulations to oppress each other. In a letter from Pennsylvanian Tench Coxe to the Virginia Commissioners, Coxe reported that while the commercial laws of Pennsylvania "exempt intirely [sic] from impost all Goods Wares or Merchandise of the growth, product or Manufacture of the United States," the laws of other (unspecified) states imposed tonnage duties on out-of-state ships and their owners "greater than [those] imposed on Vessels belonging to the Citizens of the State enacting the law" and equivalent to those imposed on foreign ships. ${ }^{120}$ Coxe also noted that discrimination existed between imported products from other states and those grown or manufactured in-state, and that these duties were sometimes as high as those imposed on foreign goods of the same kind." Such laws, Coxe wrote, were "evidently opposed to the great principles and Spirit of the Union." '22

I 7 Letter from James Madison to Thomas Jefferson (Aug. 12, 1786), in 9 Madison PAPERS, supra note 78 , at 95 .

118 See The Annapolis Convention, September, 1786, in 9 Madison PAPERS, supra note 78, at $115-16$ (editorial note).

119 See id. at 118 ("[Madison] does not discover or propose any other plan than that of investing congress with full powers for the regulation of commerce foreign and domestic.... But this power will run deep into the authorities of the individual states, and can never be well exercised without a federal Judicial.") (quoting Letter from Rufus King to Jonathan Jackson (Sept. 3,1786 ), in 8 Letters of Members of The Continental Congress 460 (Edmund C. Burnett ed., 1921-36)).

120 See Letter from Tench Coxe to the Virginia Commissioners at Annapolis (Sept. 13 , 1786), in 9 MADISON PAPERS, supra note 78, at 125 .

121 Id.

122 Id. 
After the failure of the Annapolis Convention, and prior to the 1787 convocation in Philadelphia that eventually produced the Constitution, Madison expanded work begun in 1786 in which he systematically analyzed ancient and modern constitutions, cataloguing their virtues and vices. ${ }^{123}$ Madison then turned his attention to the defects of the articles; the result was his Vices of the Political System of the United States, ${ }^{124}$ in which Madison listed twelve "vices," their causes, and possible remedies. As the editors of his papers point out "the dominant theme of Vices of the Political System ... was ... the deficiencies and derelictions of the state governments." ${ }^{125}$ Prominent among these was "[t]he practice of many States in restricting the commercial intercourse with other States, and putting their productions and manufactures on the same footing with those of foreign nations."

\section{State Commercial Discrimination, 1781-1787}

After reviewing the available commercial legislation for all thirteen states from 1781 to $1787,{ }^{127}$ it seems that several states engaged in discrimination against interstate commerce, of one sort or another, during the Confederation era. While much of this discrimination occurred in northern states such as Massachusetts, Connecticut, and New York, both Virginia and South Carolina engaged in some form of commercial discrimination as well.

As noted above, the revisionist view of the Confederation era holds that commercial discrimination among states, to the extent that it occurred at all, was very limited. Merrill Jensen wrote that there was only one dispute,

I 23 See James Madison, Notes on Ancient and Modern Confederacies (April-June, 1786), in 9 Madison PAPERS, supra note 78, at 3-24.

i 249 Madison Papers, supra note 78, at 345-58.

$125 \mathrm{Id}$. at 346.

I $26 \mathrm{Id}$. at 350 . Interestingly, Madison wrote that this practice-while "certainly adverse to the spirit of the Union, and tends to beget retaliating regulations" that themselves are "expensive \& vexatious" in and of themselves, not to mention "destructive of the general harmony"-is "not contrary to the federal articles." Id. This is a puzzling comment, considering that Article IV of the Articles of Confederation placed all citizens of the United States on equal footing and obliged states not to treat each state's citizens differently in the imposition of duties. ARTICLES OF CONFEDERATION art. IV (178I); see also infra notes 229-49 and accompanying text.

I 27 I reviewed two sets of microfiche. One at the Yale Law School; the other at Southern Illinois University School of Law. I settled on $\mathrm{I} 78 \mathrm{I}$ as a starting point, because the Articles had become effective then and the War for Independence was winding down, allowing something approaching normal trade to resume. The year 1787 was chosen as a terminating point, because by 1788 , state commercial legislative efforts would have been colored by the impending ratification of the Constitution in most places. 
between New Jersey and New York, that had its roots in the commercial policies of those states. This section will show that this is simply not true. In fact, seven states engaged in some form of discrimination against the commerce of neighboring states. In some cases, the discrimination spawned retaliatory action from other states. Virginia provides one of the clearest examples of discrimination against interstate commerce and the best example that Jensen's conclusions were in error.

\section{A. Virginia}

In 1781, the General Assembly passed An Act for ascertaining certain Taxes and Duties, and for establishing a permanent Revenue. ${ }^{128}$ Section VI of that act imposed-in addition to specified duties on liquor, wine, flour, sugar, and coffee imported "from any port or place whatsoever"-a one-percent ad valorem duty "for all other goods or merchandise which shall be imported or brought into this commonwealth ... from any port or place whatsoever." ${ }^{129}$

While the act seems clear that all goods imported were subject to duties, confusion about its scope occasioned the passage, in 1782 , of a further act intended to dispel the supposition that "the ... words 'foreign parts' were intended to exclude vessels and goods coming from any state in this union from paying the tonnage and other duties." 30 To "remov[e] ... such doubts and misconstruction," the act stated emphatically "[t]hat all vessels coming within this State from any of the United States, or from any port or place whatsoever, vessels of war excepted, shall be liable to pay the tonnage and other duties" specified in the act. ${ }^{131}$ The legislature repassed the inclusive duty as part of a consolidation of various revenue acts that took place in $1782,{ }^{132}$ and in 1784 raised the one-percent duty on imported goods to two-and-a-half percent.

Available evidence suggests that the duties remained in place even after the Constitution was submitted to the states for ratification. In 1787 , prior to Virginia's ratification of the Constitution, a group of merchants petitioned the Virginia House of Delegates requesting a repeal of duties and

I 28 Act of Nov., I 78I, Ch. XL, at 27. Unless otherwise noted, all citations for Virginia were taken from microfilmed copies of Acts Passed at a General Assembly of the Commonwealth of Vinginia at the Yale Law School and at Southern Illinois University School of Law. The session laws run chronologically. The page numbers given are those in the session laws for that year.

$129 \mathrm{Id}$. at $\$ \mathrm{VI}$.

I30 Act of May, I 783, Ch. LXXIX, § XIV, at 24, 25.

131 Id. at 25.

132 See Act of Oct., 1782 , Ch. CIII, § VIII, at 6, 9.

133 Act of May, 1784, Ch. XIII, § 2, at 8; see also Act of Oct., 1786, Ch. XXIX, at 2 I (imposing duties on liquor, cheese, tea, hemp, and cordage; tonnage duties on ships for maintenance of lighthouse). But see Act of Oct., I786, Ch. XXX, at 2 I (exempting "beer, ale, porter, or other malt liquors ... being the manufacture of the United States"). 
imposts on goods imported from other states. "' "Trade and mutual intercourse," they wrote, "ought to be free. Restrictions are inconsistent with the spirit of the Union...." Laws imposing Duties on Goods or Merchandise from any of our Sister States ... be repealed," ${ }^{136}$ and apparently they were. ${ }^{137}$

To the utter embarrassment of James Madison and other moderate nationalists, Virginia was itself a notable violator of the letter and the spirit of the Articles of Confederation. Virginia was quite clear about its trade policies; it even passed a statute to make clear its intention to tax all commerce coming into Virginia from elsewhere. Yet nowhere did Jensen discuss Virginia's discriminatory policies. Perhaps Virginia's illiberal trade policies acutely sensitized Madison to the problem of commerce, rendering it central to his thoughts of reforming the Articles.

\section{B. New York}

New York took great advantage of its port facilities. According to one historian of the period, New York's tariff "relieved the land and property of the state from heavy taxation," though it also "complicated New York's relations with her neighbors," merce imported into New York. ${ }^{139}$ According to one calculation, New York's

I34 Memorial of Winchester [Virginia] Merchants and Traders to the Vinginia House of Delegates (prior to Nov. 6, 1787), in VIII The DocumentaRy History of the Ratification of the Constitution (Merill Jensen et al. eds., 1976) (Va. 17 Microfiche Supp. 1988) [hereinafter Winchester Memorial].

135 Id.

136 Id.

I37 See Act of Jan. I, I 788, Ch. I, § V (exempting from duty "all goods, wares and merchandise ... of the growth, production or manufacture of any of the United States of America" except for distilled spirits made from imported materials), reprinted in 12 THE Statutes at large Being a Collection of All of the laws of Virginia, From the First Session of the Legislature, in the year I6I9 (William Waller Henning ed., I823).

Reprinted collections of old state statutes contain additional evidence that other enactments were repealed following the ratification of the Constitution. See Act of Feb. ro, 1787 , reprinted in I The First Laws of the State of Georgia 351 n.* (John D. Cushing ed., 198I) (noting that certain portions of an act laying duties on certain imported goods and tonnage duties was "rendered obsolete by the operation of the general government"); Act of Feb. 1,1788 , reprinted in id. at 380 (noting that "So much of this act as relates to trade and duties on imports, now under the regulation of Congress." (emphasis in original)); Act of Feb. I, 1789, reprinted in id. at 384 (omitting rates of ducies for importation of "goods, wares, liquors, merchandize and negroes" and rates of "impost on the tonnage of all vessels" arriving in the state, because "the same being under the regulation of congress").

138 E. Wilder Spalding, New York in the Critical Period, i 783-i 789, at 153 ( 1932).

$139 \mathrm{Id}$. at 156 (noting that in 1785 New York not only "took her toll from imports passing through to her neighboring states, but taxed foreign articles which reached her after importation in foreign ships through neighboring ports. The state's income from the tariff was larger than that of most other states because of the exactions upon the trade of neighboring 
tariff accounted for one-third of its total revenue during the Confederation era; landowners who were spared heavy tax burdens constituted a powerful interest group opposed to its reform.

For the most part, New York impost laws exempted goods grown or produced in other states. ${ }^{141}$ But its legislature, at one point, embargoed exports of wheat, flour, and meal to depress prices for its consumers. This of course angered her neighbors, who saw prices rise as a result. ${ }^{12}$ When the Council of Censors vetoed the embargo "on the ground that it would probably embroil the state with its neighbors who would retaliate with similar embargoes, and so ruin its trade" the Assembly passed the bill over the Council's veto with only two dissenting votes. ${ }^{13}$

In addition, beginning in 1785 , New York passed an act stating that after July I, I 786, all foreign goods imported into New York from Rhode Island, Connecticut, New Jersey and Pennsylvania "shall be subject to the like duties as are by this act imposed on all goods wares and merchandize imported into this State... in any British vessel, or any ship or vessel owned by any British subject or subjects" unless it could be proven that the imported goods were not imported into the State of origin in British ships. ${ }^{144}$ It was this act that resulted in New Jersey taking steps to tax the lighthouse owned by New York, and located on Sandy Hook. ${ }^{145}$ In this case, as in others, New York was retaliating against neighboring states that adopted freetrade policies in light of New York's policy of heavy taxation. ${ }^{146}$ For its part,

states passing through the ports of New York.") (footnote omitted); id. at 156 (commenting that New York's policy meant that Connecticut "was tributary to New York").

140 See id. at 153-54 (quoting Oliver Ellsworth's claim that opposition to reform of the tariff stemmed from legislatures being "unwillingl] to sacrifice the state impost which levied tribute on the neighboring states as well as on the merchants of New York City while it relieved the landholder") (footnote omitted).

141 See, e.g., Act of Feb. 25, I 783 , Ch. XVIII, Laws of The State of New York 533-34 ( 1783 ) (adding the proviso that "nothing herein contained shall be construed to affect the sale of any goods, wares or merchandizes of the growth produce or manufacture of this or any other of the United States of America") (unless otherwise noted, all laws cited here can be found in the microfilmed session laws, which run chronologically); Act of March 22, 1784 , Ch. X, at 599 (excepting United States goods); Act of Nov. 18, 1784, Ch. VII (exempting most other "goods wares and merchandizes of the growth, product or manufacture of the United States of America, or any of them"); Act of April I I, 1787, Ch. LXXXI, at 509 (exempting the same products).

142 Matson \& ONUf, supra note 28, at 73; Spalding, supra note 138 , at 156.

143 Spalding, supra note 138 , at 156.

144 Act of March 15, 1785 , Ch. XXXIV, at 65; see also MAtson \& ONUF, supra note 28, at 73.

145 Spalding, supra note 138 , at 157 ("In 1787 New York increased its duties and placed entrance and clearance fees upon coasting vessels. New Jersey retaliated by levying a tax of £ 30 a month on the Sandy Hook Light, kept by New York in Jersey territory.").

146 Id. (noting that in 1784 Connecticut reimposed duties in response to New York's refusal to adopt the free-trade policies Connecticut had). 
following the imposition of the 1786 tariff, Connecticut in 1787 "resolved to export nothing to New York and to furnish the latter's ships with no landing for the period of a year." 147

\section{Connecticut}

In 1784 , Connecticut passed an act establishing the cities and ports of New Haven and New London as free ports which entitled, for a period of seven years, "Foreigners and Citizens of any of the United States" who settled in either city "to pay no other or greater Duties or Taxes than the Citizes [sic] of this State residing in said Cities" were required to pay. ${ }^{148}$ The next session, however, the legislature passed a law imposing duties on wines, brandy, rum, snuff, teas, coffee, chocolate, sugar, malt liquors, and paper "imported or brought into this State, by Land or Water, from any of the United States of America"-only malt liquor manufactured in the United States was exempt. ${ }^{149}$ In the following section, though, the act exempted from a five-percent ad valorem duty "upon all other Goods, Wares and Merchandize, not before enumerated in this Act, that are ... the Growth, Produce, or Manufacture of the United States." ${ }^{150}$

It appears that the articles first enumerated were of foreign origin, but were finding their way into Connecticut through other states, perhaps ones with liberal trade policies towards foreign countries. This seems supported by the third paragraph, which exempts from the five-percent impost the property of Connecticut citizens importing foreign goods into the United States "from any foreign Port or Place, with a Design and Intent to be imported into this State." I51 In October of 1784 , however, the Connecticut legislature passed a further Impost Law which, while exempting homegrown textiles from a two-percent impost, imposed a three-pence duty "on each Pound of Sugar, other than brown Sugar, whether the Produce or Manufacture of the United States or not." ${ }^{52}$ In 1787 , the state imposed a tonnage fee on coasting vessels "bound either to the State of New York or Rhode-Island."

\section{Massachusetts}

Massachusetts' first tariff, levied in 1782 , "provided for a lengthy list of enumerated duties" including "[many]... commodities [that] were pro-

147 Id.

148 Act of May, 1784 , ConNecticut Acts, at 269.

149 Act of Jan. 1784, ConNecticut ACTs, at $27 \mathrm{I}$.

150 Id.

$15 \mathrm{I}$ Id.

152 Act of Oct. 1784, Connecticut Acts, at 309 (emphasis added).

153 Act of Oct. 1787 , Connecticut Acts, at 356. 
duced in neighboring states and were unquestionably subject to the prevailing duties," the only exceptions being sugar produced in Massachusetts and New England rum, which was favored over West Indian rum. ${ }^{154}$ In I 783, Massachusetts passed a tariff law that imposed duties on "all Goods, Wares and Merchandize [sic] of European and India Growth and Manufacture ... that shall be imported by Land or Water from any foreign Port, Island or Plantation, or any other State whatever, into this state, and landed within the same." ${ }^{155}$ No discount or remission for goods landed for re-export was permitted. ${ }^{156}$ In 1784 another law was passed, increasing the tariffs on foreign goods, especially on manufactured goods and some foodstuffs. ${ }^{157}$ Finally, in 1786 Massachusetts repealed all of its prior tariff laws, but new laws "marked the furthest advance of protectionism yet reached in the state." ${ }^{158}$ Ad valorem tariffs of fifteen percent were imposed on manufactured goods and foodstuffs; a ten-percent ad valorem tariff was imposed on wrought metals and foreign cordage; and a five-percent duty was imposed "on all other goods, wares, and merchandise of foreign growth and manufacture which would be brought in either by land or sea.... In order to encourage manufacturers certain items could not be imported at all." '59 While many of Massachusetts' tariff laws, especially those later ones, exempted American-made or -grown goods, "some duties continued to be levied against goods from other states." ${ }^{160}$ Like other states, Massachusetts imposed tonnage fees, which increased between 1783 and 1785 , and which exempted only "vessels plying between the state's ports or engaged in the fishing industry," which, not coincidentally, were likely to be owned by Massachusetts citizens.

\section{E. Rhode Island}

Stubborn Rhode Island, spoiler of all efforts to augment the revenue-raising powers of the Confederation Congress, passed a number of acts after

154 Zornow, Massachusetts Tariff Policies, supra note 27, at 198 (noting that only sugar produced in Massachusetts was exempt from 1782 duties); id. at 205 (noting that under Massachusett's 1782 tariff law; "[ $t$ ]he only concession to American producers was to be found in a provision for a lower rate from New England rum over West Indian").

I55 Act of March 22, I 783, Ch. XXXII, Acrs and Laws of the Commonwealth of MassachusetTs ( 1783 ) (emphasis added). Unless otherwise noted, all citations to Massachusetts statutes can be found in the microfilmed copies of these laws, which were published chronologically.

I 56 Id. Such a remission was apparently added the next year. $I d$. (citing Act of July I, 1784, Ch. XIII ( 1784$)$ ).

157 Zornow, Massachusetts Tariff Policies, supra note 27, at $201-02$.

158 Id. at 203.

159 ld.

I60 Id. at 207 .

I6I Id. at 208-09. 
the Revolutionary War that raised money not only from foreign commerce, but apparently from commerce originating in her sister states. In February 1783, an excise tax was placed on certain enumerated articles "for the Purpose of paying the annual Interest arising upon the public Securities of this State, or for raising a Revenue." ${ }^{162}$ Among the articles included were "Nerw-England rum" and other "imported" goods, but no blanket exemption was available to goods grown or manufactured in the United States.

In June of the same year, an additional two-percent ad valorem impost was laid on "all Goods which shall be imported into this State, being of the Growth or Manufacture of any foreign State, Island or Plantation." there was no blanket exemption for the goods of other states; the reference to foreign states could have swept broadly to include the twelve other former colonies. This impression is reinforced by the limited drawback on the impost allowed to Rhode Island citizens importing foreign goods into other states, who paid an impost of at least two percent. ${ }^{165}$ Citizens of other states would enjoy such a drawback only if their state provided a reciprocal measure for Rhode Island citizens. ${ }^{166} \mathrm{~A}$ later act stated that citizens of other states importing goods into Rhode Island "with the sole View of transporting the same ... to some other State" would be permitted to do so duty-free "[provided] the Owner ... shall produce a Certificate ... from the Collector of Impost" from the point of origin "that an Impost as high as Two and an Half per Cent. Has been paid on such Goods" and provided that the goods are neither sold nor consumed in Rhode Island.

In February 1785 , the previous two-and-a-half percent ad valorem impost on other goods, including those imported from "foreign State[s]," was retained; ${ }^{168}$ and in May, an additional seven-and-a-half percent ad valorem duty was laid on British imports, bringing the total duty to ten percent, ${ }^{169}$ which was followed by additional duties on other foreign goods in June. ${ }^{170}$ In October, Rhode Island prohibited the exportation of American goods from Rhode Island ports in ships owned in whole or in part by British subjects, and likewise closed its ports to imports brought in British bottoms. ${ }^{\text {"7 }}$

i62 Act of Feb. I 783 , Rhode IsLand Acts, at 45.

I63 Id.

I 64 Act of June, 1783 , Rhode Island Acts, at 26.

165 See id.

166 See id.

I67 Act of Aug., 1784, Rhode IsLand Acts, at 10.

I68 Act of Feb., 1785, Rhode IsLAND Acts, at 25.

I69 Act of May, 1785, RHOde IsLAND Acts, at 29.

I 70 See Act of June, 1785 , Rhode lsLand Acts, at 18.

I 7 I Act of Oct., I 785, RhODE IsLand Acts, at 29. An exception was made for ships built in Rhode Island, and the act curiously required a copy of the act be transmitted to the Governor of Connecticut. 
In December 1786 , the 1783 impost was increased by two-and-a-half percent, which again applied to goods imported from a "foreign State."

\section{F. South Carolina}

In 1783 South Carolina passed an act imposing a duty on enumerated articles and "a duty of Five per Centum on the value of all other goods imported into this State from any foreign port, island, or plantation.. ${ }^{173}$ When it became clear that duties were being imposed on goods imported from other states, the South Carolina legislature immediately declared that "it is injurious to that harmony which should ever subsist between these Federal States, to impose any duties on the commodities of the respective states" ${ }^{174}$ and authorized the refund of duties paid "on any goods, wares, or merchandizes, of the growth, produce, or manufacture of any of the United States." "75

Despite South Carolina's rejection of the discriminatory impost (at least for interstate commerce), it did impose, in 1783 , a nine-pence-per-ton duty on all ships from out of state that arrived in one of its ports, ostensibly to pay the salaries of port officers. ${ }^{176}$ The tonnage duty was increased twice during 1784 and 1785 ; in 1785 ships engaged in the coasting trade (i.e., navigating within the state) were also charged, though the rate was lower than that for out-of-state ships. ${ }^{177}$ According to William Zornow, " [t]hough most of the states were willing to admit goods grown, produced, or manufactured in the other states, they did continue to discriminate on the matter of tonnage duties." ${ }^{178}$ South Carolina's policy regarding tonnage duties was thus consistent with the practices among the several states, though prevalence rendered it no less discriminatory.

\section{State Commercial Discrimination: Evaluating the Evidence}

Not every state was engaged in commercial discrimination against its neighbors. Even those states that did impose restrictive imposts and tariffs often (but not always) took care to exempt from the higher tariffs goods grown or produced in the other states. Does that mean, then, that Jensen

172 Act of Dec., I786, Rhode Island Acts, at 21.

173 Act of Aug. 13, 1783 , Acts Passed at a General Assembly ... in the State of South Carolina I-2 ( 1783 ) [hereinafter South Carolina Acts]. All citations to the South Carolina laws refer to the microformed collection of sessions laws published annually.

174 Act of Mar. 26, 1784 , South Carolina Acts 95 ( 1784 ).

I 75 Id. at 96.

I 76 Act of Aug. 13, 1783, South Carolina Acts I-2 (1783).

177 Zornow, South Carlina Tariff Policies, supra note 27, at 39.

178 Id. 
was correct in his assessment that the issue of commercial discrimination was a red herring thrown out by men who desired above all to create a strong central government? In a series of articles published in the 1950s, historian William Zornow engaged in a survey of state legislation similar to the one undertaken here and concluded that Jensen was right: state cooperation was the norm, and that the states were becoming more cooperative with one another on commercial issues in the mid to late 1780 , not less, as the nationalists alleged. This Part argues that Zornow's interpretation of the evidence in support of Jensen's thesis was overly generous and that he largely ignores the role that the proposed Constitution of 1787 and its successful ratification may have played in encouraging states to end their parochial trade policies.

\section{A. William Frank Zornow and the Question of State Commercial Discrimination}

Though Zornow's articles were published in a variety of journals between 1954 and $1956,{ }^{179}$ they all share common claims. First, he claimed that Coxe's description of state commercial discrimination in his letter to the Annapolis Convention delegates was incorrect in several respects, ${ }^{180}$ and in general wildly overstated the problem. ${ }^{181}$ Second, he argued that whatever commercial discrimination did occur was either tempered by generous exemptions or was gradually eliminated. Finally, he asserted that "[b]y I 789," states were "admitting American products duty free, [were] granting special consideration to American ships as far as tonnage charges were concerned, and [were] treating shippers from other states the same as ["their"] own merchants." ${ }^{182}$ As the next part shows, however, Zornow's rosy conclu-

179 See supra note 27.

180 Zornow, Georgia Tariff Policies, supra note 27, at 5, 6; Zornow, Massachusetts Tariff Policies, supra note 27, at 205-07; Zornow, New York Tariff Policies, supra note 27, at 48; Zornow, Virginia Tariff Policies, supra note 27, at 312, 313.

18I See, e.g., Zornow, Ner York Tariff Policies, supra note 27, at 48 (describing Coxe's claims about discrimination against American goods as "fallacious"); see also William Frank Zornow, The Sandy Hook Lighthouse Incident of 1787 , I 4 J. Econ. HIST. 26I, 266 ( 1954) [hereinafter Zornow, The Sandy Hook Lighthouse Incident] (echoing Jensen; describing trade friction between New York and New Jersey as "a teapot tempest at best").

182 Zornow, Georgia Tariff Policies, supra note 27, at 10. Compare id. with Zornow, Massachusetts Tariff Policies, supra note 27, at 213 ("By 1789 Massachusetts, like her sister states, was moving in the direction of greater cooperation in matters of American trade. American products were being admitted duty free, and there was no attempt to discriminate against shippers from the other states as far as duties or fees were concerned."), Zornow, New York Tariff Laws, supra note 27 , at $5^{8}$ ("In 1789 New York like her sister states was admitting American products duty free and was generally treating shippers from other states the same as her own merchants. The spirit of cooperation in New York was becoming evident when one considers her tariff policies adopted during this period."), Zornow, South Carolina Tariff Policies, supra note 27, at 44 ("By 1789 the South Carolinians were moving in the direction of 
sions do not square with the evidence his survey of some state tariff policies musters.

Zornow's conclusions also raise two questions, neither of which he answers. First, was it unreasonable for Coxe, Madison, and others to conclude, as they did, that without systemic reform, commercial discrimination among the states might accelerate? Second, if cooperation was evinced by 1789 , did the Constitution of 1787 -specifically its relocation of commercial regulatory power to Congress and its concomitant restrictions on state power-contribute to that growing cooperation?

Unlike Jensen, who claimed that the so-called "Sandy Hook Lighthouse Incident" was the only example of interstate commercial friction of note during the Confederation Period, ${ }^{183}$ Zornow actually documents instances of state discrimination, which largely track those I described in Part IV. As this Part demonstrates, however, Zornow was determined to be a glasshalf-full optimist who saw incipient harmony, rather than impending crisis, in the states' legislation.

Zornow acknowledged that Virginia, ${ }^{184}$ South Carolina, ${ }^{185}$ New York, ${ }^{186}$ and Massachusetts ${ }^{187}$ discriminated to some degree against products com-

cooperation in all matters affecting tariff policies."), and Zornow, Virginia Tariff Policies, supra note 27, at 318 ("By 1789 Virginia, like her sister states, was admitting American products duty free, was granting special consideration to American ships as far as tonnage charges were concerned, and was treating shippers from other states the same as her own merchants.").

183 See supra notes $21-22$ and accompanying text.

184 Zornow, Virginia Tariff Policies, supra note 27, at 313 (acknowledging "some evidence of discrimination and retaliation in the tariff and tonnage laws of Virginia"); $i d$. at 315 (conceding that Virginia's tonnage laws discriminated at the time Coxe wrote his letter, but arguing that the "situation ceased to exist ... in 1786 when the new tonnage fees went into operation").

I 85 Zornow, South Carolina Tariff Policies, supra note 27, at 35 (noting that South Carolina discriminated against goods coming from other states until $1783-84$, when it exempted American goods from its impost and pursued a policy of free trade). But see id. at 38-39 (describing tonnage duty levied on ships coming into the South Carolina port from outside the state; exemption for vessels owned by state residents "enraged merchants throughout the country"); id. at 39 ("Though most of the states were willing to admit goods grown, produced, or manufactured in the other states, they did continue to discriminate on the matter of tonnage duties.").

186 Zornow, New York Tariff Policies, supra note 27, at 48 (conceding that New York's I 788 tariff was protectionist); $i d$. at 49 (noting "evidence of discrimination and retaliation in the tariff and tonnage laws of New York"); $i d$. at 50 (discussing tariff laws aimed at goods coming from Rhode Island, Connecticut, New Jersey, and Pennsylvania); id. at 53 (noting discrimination against out-of-state loaf sugar, tea, and hemp imposed in 1784 ; describing tonnage fees that exempted New York ships).

I 87 Zornow, Massachusetts Taniff Policies, supra note 27, at 198 (noting that only sugar produced in Massachusetts was exempt from 1782 duties); id. at 200 (discussing 1783 law imposing tariff on goods from other states); $i d$. at 205 (noting that Massachusetts' 1782 tariff law "provided for a lengthy enumerated list of duties" including "[many] ... commodities [that] were produced in neighboring states and were unquestionably subjected to the prevailing 
ing from other states, either through impost duties or by discriminatory tonnage fees imposed on out-of-state ships. Zornow also conceded that discriminatory tariffs played a role in the friction between New York and New Jersey that produced the "Sandy Hook Lighthouse Incident of $1787 . "$ "188 And yet, Zornow termed "fallacious" ${ }^{189}$ the claims made by Coxe, among others, that many states were discriminating against interstate commerce either through discriminatory tariffs that treated out-of-state products no different (or worse) than foreign goods, or through tonnage duties that indirectly taxed out-of-state imports. On the contrary, Zornow concluded that every state he examined was moving toward economic cooperation and free trade by $1789 .{ }^{190}$ What discrimination that existed or remained by then,

duties"; "[r]he only concession to American producers was to be found in a provision for a lower rate from New England rum over West Indian"); id. at 206-07 (noting that, after 1783, "[r]here was an increasing tendency to admit American grown, produced, and manufactured commodities duty free into Massachusetts' ports," but admitting that "some duties continued to be levied against goods from other states"); id. at 208-09 (describing a tonnage duty on ships entering Massachusetts ports, which exempted "only... vessels plying between the state's ports or engaged in the fishing industry").

I 88 See Zornow, The Sandy Hook Lighthouse Incident of 1787 , supra note 181, at 263-66.

I89 Zornow, New York Tariff Policies, supra note 27, at 48 ("It has already been demonstrated that Coxe's claim that American products were discriminated against by the tariff enactments of each state was fallacious."); Zornow, Virginia Tariff Policies, supra note 27, at 312 (Coxe's objection "that American produced and grown goods were dutiable at equal or higher rates than similar goods brought from foreign lands" was "not entirely true in Virginia"); see also Zornow, Geongia Tariff Policies, supra note 27, at 6 ("One of Coxe's objections had been that American produced and grown goods were dutiable at equal or higher rates than similar goods brought from foreign lands, but this was not true in Georgia."); Zornow, Massachusetts Tariff Policies, supra note 27, at 207 ("Coxe's claim that American products were discriminated against by the tariff enactments in each state was not true in Massachusetts.").

190 See Zornow, Georgia Tariff Policies, supra note 27, at 10 ("By 1789 Georgia, like her sister states, was admitting American products duty free, was granting special consideration to American ships as far as tonnage charges were concerned, and was treating shippers from other states the same as her own merchants. The criticism of men like Coxe was unfounded."); Zornow, Massachusetts Tariff Policies, supra note 27, at 213 ("By 1789 Massachusetts, like her sister states, was moving in the direction of greater cooperation in matters of American trade. American products were being admitted duty free, and there was no attempt to discriminate against shippers from other states as far as duties or fees were concerned."); Zornow, New York Tariff Policies, supra note 27 , at 58 ("In 1789 New York like her sister states was admitting American products duty free and was generally treating shippers from other states the same as her own merchants. The spirit of cooperation in New York was becoming evident when one considers her tariff policies adopted during this period."); Zornow, South Carolina Tariff Policies, supra note 27 , at 43,44 ("By 1787 South Carolina was moving in the direction of cooperating in tariff affairs not only with her sister states but with the central government as well .... By 1789 the South Carolinians were moving in the direction of cooperation in all matters affecting tariff policies."); Zornow, Vinginia Tariff Policies, supra note 27 , at 318 ("By 1789 Virginia, like her sister states, was admitting American products duty free, was granting special consideration to American ships as far as tonnage charges were concerned, and was treating shippers from other states the same as her own merchants. The spirit of cooperation in Virginia was becoming quite evident, and it is apparent not only in dealings with other 
Zornow wrote, was aimed against foreign states that refused to conclude a commercial treaty with the United States, ${ }^{191}$ treated out-of-state products no worse than those from other countries ${ }^{192}$ (and better, in some cases ${ }^{193}$ ), or was the exception rather than the norm.

Zornow's treatment of New York and New Jersey's clash over the Sandy Hook Lighthouse is illustrative. ${ }^{195}$ The incident, Zornow wrote, had been overemphasized by those sympathetic to Fiske's "Critical Period" thesis, and its repeated citation was contrary to what Zornow saw as the movement towards greater cooperation among states on matters of trade. ${ }^{196}$ Zornow argued that, in fact, the New York statute that so angered New Jersey and Connecticut actually reduced some levies on ships from those commonwealths. ${ }^{197}$ As with his discussion of specific states, Zornow's interpretation stressed that the burden was not as much as contemporary writers and nineteenth-century historians claimed, though even his sanguine

states but in those with the central government as well.").

191 Zornow, Virginia Tariff Policies, supra note 27, at 313; see also Zornow, Georgia Tariff Policies, supra note 27, at 1o ("Any discrimination that is evident in Georgia was directed against foreign states which did not conclude a treaty with the United States."); Zornow, New York Tariff Policies, supra note 27, at 49 ("There was some evidence of discrimination and retaliation in the tariff and tonnage laws of New York, but most of it was aimed against foreign states rather than against other American states. The discrimination against England is particularly noticeable."); Zornow, South Carolina Tariff Policies, supra note 27, at 44 ("Any discrimination in the South Carolina tariff legislation was directed against the British, while other foreign countries which concluded commercial treaties with the United States were accorded special concessions.").

192 See, e.g., Zornow, Massachusetts Tariff Policies, supra note 27, at 207 ("Although some duties continued to be levied against goods from other states, they were in no case greater than the duty being imposed on similar foreign goods."); Zornow, New York Tariff Policies, supra note 27, at 50 (discussing 1785 law subjecting goods imported from Rhode Island, Connecticut, New Jersey, and Pennsylvania to duties imposed on goods imported in British-owned or -built ships; explaining that "it was discrimination against products brought originally to the four enumerated states in British bottoms").

193 See, e.g., Zornow, Georgia Tariff Policies, supra note 27, at 7 (discussing "special reductions" in Georgia's tonnage fees "which were designed to encourage the American merchant marine and commerce" and which were "a direct refutation of Coxe's claims"); Zornow, Vinginia Tariff Policies, supra note 27, at 315 (noting that "American ships were given special concessions on the matter of tonnage charges over foreign ships").

194 See, e.g., Zornow, South Carolina Tariff Policies, supra note 27, at 44 ("In some states there was discrimination against vessels owned by non-residents of the enacting states in the matter of tonnage fees, but in South Carolina this practice was minimized."); Zornow, Vinginia Tariff Policies, supra note 27 , at 313 (noting that "[n] early every state sought to bring [England] to terms by adopting some discriminatory legislation against West Indian and British trade").

I95 See Zornow, The Sandy Hook Lighthouse Incident of 1787 , supra note $18 \mathrm{I}$.

I 96 See id. at 261.

197 See id. at 264-65. 
interpretation of the incident included many examples of discrimination that would have concerned the moderate nationalists.

In late 1787 , according to contemporary accounts, New York began imposing hefty tonnage fees on boats coming from New Jersey-fees that treated New Jersey ships entering and clearing in New York ports like other "foreign" ships. ${ }^{199}$ New Jersey, which had long wearied of having its commerce taxed by New York, retaliated by imposing a hefty annual rent on a New York lighthouse that sat at the tip of Sandy Hook, New Jersey. ${ }^{200}$ Zornow wrote, however, that to focus on the burden the New York statute imposed on New Jersey's shipping was to miss its real significance: "When one compares the New York law of $1787, \ldots$ it can be clearly seen that instead of being solely discriminatory it actually extended many privileges to American ships from New Jersey and Connecticut that were overlooked by contemporaries and later writers." ${ }^{201}$

In 1784, when the New York customs authority was established, the law prescribed a fee of three pounds for any American-owned ship over 150 tons to enter and clear, one pound, ten shillings for ships between 70 and 150 tons, and sixteen shillings for ships less than 70 tons. ${ }^{202}$ Ships of less than 20 tons traveling between states or between New York ports were able to enter without fees, unless the goods they carried were subject to tariff duties. ${ }^{203}$ Upon passage of the 1787 law, which triggered the punitive rent on New York's lighthouse, "there was a substantial reduction of fees amounting to fifty per cent on American-owned vessels under twenty tons, and twenty-five per cent on ships from twenty to forty tons burden that entered New York" from either Connecticut or New Jersey. ${ }^{204}$ Reductions for ships without dutiable goods were "even more marked."

However, Zornow pointed out that "decked vessels of less than twenty tons that carried American products... were now subjected to a fee of two shillings," meaning that "New Jersey farmers selling goods in New York

198 See id. at 262-65 (describing the commercial friction among New York, New Jersey, and Connecticut).

199 Id. at 262.

$200 \mathrm{Id}$. at 263.

201 Id.

202 See id.

203 See id. at 263-64.

$204 I d$. at 264 ("[V]essels from forty to seventy tons paid twenty shillings, those from twenty to forty tons paid twelve shillings, and those decked vessels under twenty tons burden paid eight shillings. Undecked vessels entered free of charge.").

205 Id. ("Vessels of from forty to seventy tons burden paid only five shillings, which was a saving of eleven shillings. Those from twenty to forty tons paid only three shillings, which amounted to a reduction of thirteen shillings over the entrance and clearance fees collectible under the law of $1784 . "$ ) (footnote omitted). 
were compelled to pay a fee high enough to discourage their trade." ${ }^{206} \mathrm{He}$ repeated this later, writing that New York's I 787 tariff "was obviously designed to check the importation of truck products from New Jersey and Connecticut." ${ }^{207}$ New Jersey, which levied the heavy rent on New York's lighthouse, and Connecticut, some of whose merchants boycotted New York markets, ${ }^{208}$ retaliated because of a "long period of ill feeling between the ... states" for whom "[t]he law of $\mathrm{I} 787$ was the last link in a long chain of injustices." 209

Given Zornow's description, one might think him sympathetic to the beleaguered states, which had long tired of trading under New York's sizable thumb; or at least understanding of their failure to be impressed with what Zornow characterized as the law's reformist spirit. Instead, Zornow expressed surprise that the focus would have been on what he considered to be a relatively trivial increase in tariffs, and not on the concessions the 1787 act contained. Despite the discriminatory purpose of the 1787 tariff-to disadvantage imports from New Jersey-Zornow noted that such goods could still be brought in without charge "in undecked vessels" and added, without any support, that "it must have been true that a large percentage of the products entered via this type of transportation." ${ }^{210}$ Why? Given the desire to protect its own products, New York might just have easily offered an exemption that was of little use to New Jersey merchants. Given the history of commercial animosity between New York and New Jersey, it is reasonable that any increase in tariffs on New York's part would have been deeply resented, overshadowing any concessions (assuming the concessions benefited New Jersey's merchants), which would, in any event, likely have been regarded with considerable suspicion.

Zornow's treatment of the Sandy Hook Lighthouse Incident is consistent with his Panglossian approach to state trade laws generally. In this case, he concluded that the incident "was a teapot tempest at best" and that "even this one example of discrimination among the states was tempered with exceedingly liberal concessions," ${ }^{211}$ just as he assumed that instances of discrimination among state laws were incidental and paled in comparison with the "trend" he saw towards trade liberalization by the late ${ }_{1780 s^{212}}{ }^{2}$ Most interested observers of the time saw things differently. States eager to gain commercial advantage and retain the revenue that trade afforded, like New York, passed laws that palpably affected the com-

206 Id.

207 Id. at 265.

208 See id. at 265 n.12.

209 Id. at 265.

210 Id. at 264.

211 Id. at 266.

212 See supra notes $184-94$ and accompanying text. 
merce of other states. Aggrieved states retaliated. That this cycle persisted on the eve of the drafting of the U.S. Constitution suggests that the contemporary observers had reason to be concerned. Zornow (and Jensen) said those observers were either alarmists or were sounding the tocsin to further their own economic interests-interests which benefitted from a stronger central government.

Who is right? Was state discrimination a "teapot tempest" or had the new union entered a "critical period," as John Fiske famously claimed? Historians will likely continue to debate that question. But there are reasons, outlined in the next section, which cast doubt on Zornow's optimistic interpretation of events.

\section{B. Evaluating Zornow}

While Zornow undoubtedly performed a valuable service by reading and describing state tariff laws, there are sound reasons to doubt his interpretation of 1780 s events. The first is his apparent lack of interest in whether the Constitution played a role in the liberalization of trade by 1789 . The second concerns his use of Coxe's letter to the Virginia Commissioners as a straw man, while ignoring much of what his own evidence suggested about the state of commercial regulation during the Confederation era.

1. Zornow's Curious Omission. - It is interesting that Zornow chose the year I 789 as the year by which states had largely adopted policies of non-discrimination towards out-of-state commerce but omitted any discussion of the adoption of the Constitution of 1787 , which limited state regulation of commerce, as a possible causal factor in the liberalization of interstate trade. Zornow's omission suggests that adoption of free-trade policies was entirely due to an embrace of enlightened self-interest by the states themselves, as opposed to a reaction to the Constitution's new limitation of state commercial regulation. As I shall show in the following part, the explicit textual provisions placed in the Constitution were designed to eliminate from states' regulatory repertoire the particular items-imposts and tonnage fees-that caused so much friction during the Confederation period. Failure even to mention the Constitution of 1787 in the evolution of states' tariff policies is, as the saying goes, to stage Hamlet without the Prince. Zornow's omission is akin to a historian noting that slavery had disappeared in the United States by 1866 without mentioning either the Civil War or the Thirteenth Amendment.

The question of whether states would have given up self-serving trade policies in the absence of the Constitution is counterfactual and unanswerable with certainty. It is possible, but unlikely, that they would have. States repeatedly rejected attempts to grant power over revenue and trade to the central government. States ignored the free-trade provisions present in the 
Articles of Confederation, which were unenforceable in any event. The trend in the mid-I 780s was toward higher tariffs and tonnage duties in some states. Even when ostensibly aimed at foreign trade, laws were passed to discourage diversion of trade to states with low tariffs or with free ports. At least one state used embargoes to create an artificial glut and lower prices within the state, while raising prices in neighboring states. States did not take this economic collateral damage lying down; the targets and victims of such policies did not hesitate to pass retaliatory laws in response.

These facts, which were borne out by the laws that the states were passing, are relevant to making an assessment of whether the Framers exaggerated the degree of strife, or whether they were alarmist in their assessments about the likely fate of the United States. Zornow claimed his evidence supported Jensen's conclusion that the Framers' fears were exaggerated and they stoked a sense of crisis to get the strong national government they favored, and which would be favorable to their economic interests. The next section describes why one should have second thoughts about Zornow's and Jensen's conclusions.

\section{Does Zornow Prove the Nationalists Were Alarmists? - Zornow seemed} committed to disproving the Critical Period thesis and clearly aligned himself with Jensen's revisionist view. He marched through the relevant impost and tonnage statutes in all of his articles toward the inevitable conclusion that criticisms, like those of Coxe in 1786 , that states were forcing their neighbors to pay higher imposts and tonnage duties than they were charging foreign countries was totally false, and that, in fact, the trend during the Confederation period was towards a policy of universal free trade for interstate goods. The problem is not so much that Zornow missed the evidence (as Jensen did). The problem, rather, is in his interpretation of those materials, which is seriously deficient. Careful attention to what exactly Zornow did in his articles, moreover, shows there to be less than meets the eye.

First, Zornow took Coxe's letter literally. What Zornow set out to refute, then, was not so much the propositions that state discrimination existed, that it worried political leaders, and that they committed themselves to reforming the governmental structure that provided no effective remedy against such discrimination, but something more specific. Zornow took Coxe's complaints at face value, and attempted to show that (1) most Americanmade products were exempted from tariffs, even if some discriminatory tonnage duties were left in place, and (2) out-of-state goods were not generally treated worse than foreign goods, as Coxe claimed. Finally, Zornow pressed his argument that the overall trend was toward trade liberalization, at least by 1789 .

As noted above, the choice of 1789 is an important qualification that does not necessarily refute the Critical Period thesis. Fiske himself might 
agree: yes, by 1789 free trade was the order of the day-because the nationalists succeeded in framing and successfully ratifying a constitution that mandated free trade policies.

Second, as noted earlier, the exemptions in place for domestic manufacturers do not necessarily mean that there was perforce no discrimination against out-of-state commerce. Whatever their aim-raising revenue, piecemeal retaliation at Great Britain-many of the tariffs and tonnage duties affected merchants and consumers of other states, either because out-of-state merchants operating in states with free ports found their goods taxed as they moved them into another state for sale, or because states with advantageous ports took advantage of their locale by imposing heavy duties on goods eventually consumed in states, like New Jersey or Rhode Island, which lacked good port facilities. Simply because the tariffs were not always aimed at "New England rum," "Virginia tobacco," or "Massachusetts textiles" does not mean that they affected other states' merchants any less.

Third, that out-of-state goods were often treated on par with foreign goods-that is, they were not taxed at a higher rate than foreign goodscan hardly be taken as a mark of trade liberalization in the Confederation period. The Constitution-even the Articles of Confederation-required out-of-state commerce to be treated no worse than the internal commerce of the states. Moreover, states were theoretically restricted from interfering with commercial treaties negotiated by the Confederation government with foreign countries.

Finally, Zornow's conclusions gloss over the fact that real discrimination against domestic goods and against particular states did occur. Coxe's statement might have been a bit of chamber-of-commerce boosterism designed to show Pennsylvania in a good light, ${ }^{213}$ but his complaints were not entirely fictional, even if they were incorrect in certain particulars.

One does not have to accept Fiske's extreme characterization of the Confederation period to conclude, pace Zornow and Jensen, that interstate discrimination (along with the general lack of mechanism to effect a uniform national trade policy) was hindering the development of the United States and was, by $I 787$, causing friction among its constituent members. Historian Richard Morris, commenting on the writings of Jensen and others, put the matter this way: "Despite an overwhelming body of evidence to the contrary, sympathizers with the Antifederalist position have charged that the bad times of the postwar years were the figment of the imagination of nationalist propagandists." ${ }^{214}$ As the economy worsened in the mid-1 $780 \mathrm{os}^{215}$ states levied tariffs "[t]o secure revenue, prevent dumping of

213 See Jacob E. Cooke, Tench Coxe and the Early Republic 96 (1978).

214 MoRris, supra note 37 , at 133 .

215 According to Morris, 1784 was the year of the first American depression. See id. at 134 . 
foreign goods, and protect emerging native industries"; the revenue thus obtained inured to the benefit of the states and not to Congress. ${ }^{216}$ Morris commented that

the state tariffs failed to provide a truly common market within the thirteen states, a major objective of the later federal Constitution. In addition to being discriminatory, they lacked uniformity in the degree of protection offered home industry and production, and their objectives diverged as regards the trade patterns they sought to shape. ${ }^{217}$

Perhaps more important is what the Framers saw as the perceived threat to the union posed by the legislative activity of the states. As Clinton Rossiter wrote,

Whether the United States in 1787 was in truth on the edge of dissolution is a question that will be argued among historians until the United States is no more. That a majority of the continental elite believed this to be the truth is the most solid, incontrovertible fact in the records of that year. ${ }^{218}$

The Framers' contemporary comments bear out this observation. Alexander Hamilton spoke for many when he wrote in The Federalist No. $22^{219}$ that "interfering and unneighborly regulations of some States, con-

216 Id. at 148 .

217 Id. at 149 (emphasis added).

2 I 8 Clinton Rossiter, i787: The Grand Convention 57 (1966). Madison's biographer made a similar point:

Though the economic distress, commercial warfare, and paper money "depravity" of the Confederation may have been exaggerated by Madison and others at the time, and by "critical period" historians ever since, it is important to remember that Madison's anxiety and concern rested as much on tendencies as on actuality. The amicable settlement of some disputes among states was to him less significant than the looming unresolved issues. He declaimed not about the lack of patriotism of the defenders of state supremacy, but against their unwisdom and their failure to envision the inevitable debilitation that would result from the deficient authority of the general government under the Articles of Confederation.... Madison was convinced that in the long run the United States required government over, not negotiation among, its constituent parts.

Ralph Ketcham, James Madison: A Biography i 76 (Univ. Press of Va. 1990) (197I) (footnote omitted); see also Christopher R. Drahozal, On Tariffs Versus Subsidies in Interstate Trade: A Legal and Economic Analysis, 74 WASH. U. L.Q. I 127 , I 181 n.267 (1 996) ("[W] hat matters most for interpretive purposes is not what actually happened, but what the founders believed had happened or could happen.").

219 I assume that the views expressed in The Federalist are reliable statements (if occasionally finessed) of the views and opinions of the primary authors, Madison and Hamilton. On the reliability of The Federalist for constitutional interpretation, see generally William N. Eskridge, Jr., Should the Supreme Court Read'The Federalist but Not Statutory Legislative History?, 66 Geo. Wash. L. Rev. I3OI (1998). 
trary to the true spirit of the Union, [had] given just cause of umbrage and complaint to others." ${ }^{220}$ He further warned "that examples of this nature, if not restrained by a national control, would be multiplied and extended till they became not less serious sources of animosity and discord than injurious impediments to the intercourse between the different parts of the Confederacy." and to the "multiplicity of the duties which the several princes and states [in Germany] exact upon the merchandises passing through their territories," ${ }^{222}$ Hamilton wondered whether "we may reasonably expect, from the gradual conflicts of State regulations, that the citizens of each would at length come to be considered and treated" by other states as "foreigners and aliens." 223

One commentator remarked that "historians may well be correct that there were in reality far fewer interstate trade barriers than once believed." ${ }^{224}$ The fact remains, however, that these same historians have excessively downplayed the level of discrimination that existed as well as how that discrimination was perceived by men like Madison, who only came to the conclusion that the Articles required major revision reluctantly, and have ignored the possibility that the Framers' actions were not only reactive, but also prophylactic, seeking a measure of protection against further future disputes. As Professor Drahozal noted, "Even if those disputes were relatively rare, they did happen and could have happened again if not guarded against in the Constitution." ${ }^{225}$ It is those constitutional safeguards to which I turn in the next section.

\section{Constitutional Limitations on State Commercial Regulation}

In this part, I argue that constitutional protections against interstate discrimination, which constitute the bulwark of the modern DCCD, find their origins in four provisions of the 1787 Constitution. First, the Commerce Clause, which committed power to regulate interstate commerce to Congress, was seen mainly as a restraint on state power. This affirmative grant of power was bolstered by the three explicit limitations on state power: the Import-Export Clause, the Tonnage Clause, and the Privileges and Immunities Clause of Article IV. I begin, however, with the drafting history of the Articles of Confederation, the provisions of which furnish a response

220 The Federalist No. 22, at I44 (Alexander Hamilton) (Clinton Rossiter ed., I96I). Hereinafter all citations are to this edition.

22 I Id. at 144-45.

222 Id. at 145.

223 Id.

224 Drahozal, supra note 2 i 8 , at I 180 n.267.

225 Id. at I I $80-8$ I n.267. 
to those who assume that the era's concern for preservation of state sovereignty render any historical or textual arguments for the DCCD untenable. In fact, from the early days of the Republic, a concern existed that control of commerce could serve as a wedge between'states, and handicap the incipient union. The Articles themselves provided nascent protections for interstate commerce, though not as many as their drafters would have preferred. The lack of any enforcement mechanism in the Articles, however, rendered the protections that survived entirely theoretical.

\section{A. State Commercial Regulation and the Articles of Confederation}

Early drafts of the Articles of Confederation, written by John Dickinson, included significant restraints on the power of states to discriminate against interstate commerce. Though many of Dickinson's provisions were not adopted by the Continental Congress, the articles, as ratified, were not wholly lacking in protections for interstate commerce. Limited in scope and unenforceable as they were, the provisions of the articles regarding treaties, trade, and the treatment of other states' citizens nevertheless suggest that some embryonic principle of economic union was emerging despite the articles' well-documented preservation of near-absolute state sovereignty. ${ }^{226}$

As early as $\mathbf{1 7 7 6}$, just after independence, pamphleteers were calling for the formation of a general government of the newly independent states that would make "general regulations respecting trade." ${ }^{227}$ John Dickinson, the Pennsylvanian who headed a committee charged with drafting the Articles of Confederation, understood that uniformity could not be obtained if states were accorded complete power over their commercial regulations.

Dickinson's draft of the articles included a number of interesting protections for interstate commerce. ${ }^{229}$ Two of the articles "would have prohibited the states from enacting measures discriminating against the inhabitants of other colonies, most importantly in matters of trade." ${ }^{230}$ First, "[i]nhabitants of each Colony" were guaranteed "the same Rights, Privileges and advan-

226 ARTICLES OF CONFEDERATION art. II.

227 Jack N. Rakove, The Beginnings of National Politics: An INTerpretive History of the Continental Congress 149 (1979).

228

Implicit in [Dickinson's] conception of confederation ... was the premise that the states were incapable of entirely regulating their activities in the best interest of union, and that any plan of confederation would therefore have to impose restraints on their sphere of action-and not merely in areas that obviously required the general direction of Congress.

Id. at 152.

229 See Josiah Bartlett's and John Dickinson's Draft Articles of Confederation (June 17, 1776), in 4 Letters of Delegates to Congress, i 774-1 789, at 233 (Paul H. Smith ed., r979) [hereinafter Dickinson Draft].

230 Raxove, supra note 227 , at 153. 
tages in all Cases whatever in the other Colonies, which they now have."231 They were also to enjoy "all the Rights, Liberties, Priviledges [sic], Exemptions \& Immunities in Trade, Navigation \& Commerce in every Colony, and in going to $\&$ from the same, which the Natives of such Colony enjoy." ${ }^{232}$ The same article also stated that "[n]o Colony shall assess or lay any Duties or Imposts on the Importation of the Productions or Manufactures of another Colony, nor settle or establish any Fees for Entries, Clearances, or any Business whatever relative to Importation or Exportation." ${ }^{233}$ However, the new states retained the power to levy duties and imposts on foreign commerce, as long as those impositions did not conflict with treaties of the United States. ${ }^{234}$

As historian Jack Rakove wrote: "When [Dickinson] proposed ... prohibiting the states from discriminating against each other's citizens, he recognized how easily questions of interests could evoke interstate conflicts. Dickinson clearly intended to use confederation as a vehicle not only for defining the powers of Congress but also for limiting the authority of the states." 235 Unfortunately, others on Dickinson's committee did not share his vision and stymied his efforts to "minimize the most obvious sources of internal conflict" ${ }^{236}$ threatening the national unity "that all whig leaders continued to agree was necessary to American success." ${ }^{237}$ In the end, the Committee deleted the prohibition on interstate commercial discrimination and converted the grant of authority to levy duties and imposts on foreign commerce into a grant to levy them on all imports and exports. ${ }^{23^{8}}$ After the draft was debated in Congress, the remaining restraints were removed as well. ${ }^{239}$ "Congress rejected the ... Articles, which contained the

231 Dickinson Draft, supra note 229, at 236.

$232 I d$.

$233 \mathrm{Id}$.

234 See id. at 237 :

Each Colony may assess or lay such Imposts or Duties, as it thinks proper, on Importation or Exportations (to the British Dominions, or any foreign Kingdom or State, on the Importation of the productions or Manufactures of such (...J or any foreign Kingdom or State from another Colony), provided such Imposts or Duties do not interfere with any Stipulations in Treaties hereafter entered into by the Union, with the King or Kingdom of G[reat] B[ritain] or with any foreign Prince or State.

235 RAKove, supra note 227, at 157.

236 Id. at 158.

237 Id.

238 See Dickinson Draft, supra note 229, at 237. Compare 5 Journals of the Continental Congress I 774-1789, at 547-48 (Government Printing Office ed., 1906) (reprinting the first copy laid before Congress).

239 See 5 Journals of the Continental Congress 1774-1 789, supra note 238, at 67489. 
prohibitions against state measures that would discriminate against citizens of other states." 240

At first glance, the actions of the Continental Congress suggest a complete repudiation of Dickinson's vision for the confederacy and a shift in the focus from addressing possible sources of conflict within the constituent members of the new nation to a jealous protection of state sovereignty against encroachment from the new Congress. ${ }^{21}$ However, some restrictions on the power of states were reintroduced and became part of the document that was eventually ratified by the states.

Article IV-the progenitor of the Privileges and Immunities Clause of Article IV of the U.S. Constitution ${ }^{243}$ - (I) granted to citizens of each state the rights of "free ingress and regress" to and from the several states; (2) guaranteed the "privileges of trade and commerce" in the states on the same terms as citizens of those states; and (3) secured the right to remove "property imported into any state, to any other state" inhabited by the owner of that property. ${ }^{244}$ Article VI echoed Dickinson's limitation on the power of states over foreign commerce and forbade the laying of imposts and duties by states in any manner that interfered with proposed treaties with France and Spain. ${ }^{245}$ Article IX stated that the Confederation Congress had the "sole and exclusive right and power of ... entering into treaties and alliances," but provided that no commercial treaties could be made whereby states were "restrained from imposing such imposts and duties on foreigners, as their own people are subjected to, or from prohibiting the exportation or importation of any species of goods or commodities whatsoever. ${ }^{246}$ Note, however, that by negative implication Congress could have, by treaty, restrained states from laying imposts and duries greater than those to which their own citizens were subject - an additional (if only a potential) restraint on the states.

As Rakove pointed out, "[e]ach of these prohibitions involved some function of government related to the internal police of the states but whose exercise could prove inimical to the tranquility of the union." ${ }^{247}$ Though the final draft provided explicit protections for state sovereign$\mathrm{ty}^{248}$ and insured that states would have near-absolute power to regulate

240 RAKove, supra note 227 , at 160.

241 See id.

242 See id. at $18 \mathrm{I}-82$.

243 See U.S. Const. art. IV, $§ 2$.

244 Articles of Confederation art. IV.

245 See id. art VI.

246 Id. art. IX.

247 Rakove, supra note 227 , at 181.

248 ARTicles of Confederation art. II. ("Each state retains its sovereignty, freedom and independence, and every power, jurisdiction and right, which is not by this Confederation expressly delegated to the United States, in Congress assembled."). 
their own affairs, "the confederation would nevertheless establish certain limits on their sovereignty other than those required by the exigencies of war and diplomacy." ${ }^{299}$ Far from repudiating Dickinson's earlier work, the Continental Congress, in part, adopted a few of his principles. ${ }^{250}$

Thus, even during the high-water mark for the constitutional protection of state sovereignty, the delegates drafting the Articles of Confederation recognized that interstate discrimination in commercial matters was inconsistent with the project of union on which the states had embarked. Moreover, as we shall see, some of the language deleted from Dickinson's initial draft tracks language that became part of the Constitution.

\section{B. The Constitution of 1787 and Restrictions on State Regulation of Commerce}

I. The Commerce Clause.-The Framers in Philadelphia solved one of the problems that bedeviled the Confederation Congress-inability to pass uniform trade policies and raise revenue-by empowering Congress to "lay and collect Taxes," including "Duties, Imposts, and Excises," "[t]o regulate Commerce with foreign Nations, and among the several States, and with Indian Tribes." ${ }^{252}$ Though the degree to which the latter grant of power itself implicitly restrained states and whether courts are warranted in enforcing any implicit restriction are questions at the heart of the controversy over the DCCD, it appears that the grant of power to Congress was intended as a corrective to the state commercial regulation regimes under the Articles of Confederation.

Madison famously propounded this "restrain-the-states" thesis in I829, writing that the Commerce Clause "grew out of the abuse of the power by the importing States in taxing the non-importing, and was intended as a negative and preventive provision against injustice among the States themselves." ${ }^{253}$ Madison's letter has often been cited as authority for the DCCD, ${ }^{254}$ though critics have argued that neither members of the Philadelphia Convention nor delegates to state ratifying conventions shared Madison's views. ${ }^{255}$ Then-professor Felix Frankfurter once flatly

249 Rakove, supra note 227 , at 182.

250 For an earlier description of the fate of Dickinson's draft, see MerriLl JeNSEN, The Articles of Confederation: An Interpretation of the Social-Constitutional History OF THE AMERICAN REVOLUTION, I 774-I 781, at 133, 137-39, 177-78 ( 1940).

25 I U.S. Constr. art. I, \& 8, cl. I.

252 Id. at cl. 3.

253 Letter from James Madison to J.C. Cabell (Feb. 13, 1829), reprinted in 3 The Records of THE Federal, Convention of 1787 , at 478 (Max Farrand ed., rev. ed. 1966) (hereinafter RECORDS].

254 See, e.g., West Lynn Creamery, Inc. v. Healy, 512 U.S. 186, 193 n.9 (1994).

255 Camps Newfound/Owatonna v. Harrison, 520 U.S. 564, 613 n.7 (1997) (Thomas, J., 
declared that the notion that "the mere grant of the commerce power to Congress dislodged state power finds no expression" in the debates of the delegates to the Philadelphia Convention or in the debates of state ratifying conventions. ${ }^{256}$ Given the extent to which the Framers were concerned with state regulatory mischief, it would be surprising to find no support for this proposition, which the Supreme Court has itself invoked in support of the DCCD. As Barry Cushman has pointed out, prior to the late nineteenth century, litigation involving the Commerce Clause involved not the affirmative power of the federal government, but the restrictions on state regulation of commerce. ${ }^{257}$ The analytical categories with which the Court wrestled, and ultimately abandoned after 1937 , in fact were largely the flip side of the analytical categories developed for applying the DCCD.

In I94I, five years after Frankfurter dismissed arguments that the grant of power over commerce could be construed as an implicit restriction on state power, Albert Abel published an exhaustive survey of the extant records of both the Philadelphia and state ratifying conventions. ${ }^{258}$ Abel concluded that the majority sentiment was in favor of federal exclusivity in matters of commercial regulation of primary concern to conventions, viz., the impediments to trade canvassed above, which set states against one another in matters of trade. Abel found "strik[ing]" the "nearly universal agreement that the federal government should be given the power of regulating commerce," that the lack of power under the Confederation was a hindrance to union, and that "its grant" would be "a major and indubitable boon of union." ${ }^{259}$ Not only was the Commerce Clause adopted unanimously, and without debate in Philadelphia, but "[i]n the ratifying conven-

dissenting); see also Redish \& Nugent, supra note 2, at 587-88; Lisa Heinzerling, The Commercial Constitution, 1995 Sup. CT. Rev. 217,219 n. 12 (1995).

256 Felix Frankfurter, The Commerce Clause Under Marshall, Taney, and Waite 13 (1937).

257 Seegenerally Barry Cushman, Formalism and Realism in Commerce Clause Jurisprudence, 67 U. ChI. L. Rev. 1089 (2000).

258 Albert S. Abel, The Commerce Clause in the Constitutional Convention and in Contemporary Comment, 25 Minn. L. Rev. 432 (1941).

259 Id. at 443-44. Elsewhere, he wrote:

An outstanding defect under the articles, it was commonly felt, was the lack of power in the United States either to raise a revenue to meet expenses and discharge the continental debt or to cope with discriminatory commercial regulations of foreign countries, in particular of Great Britain.... Moreover, the states were using their imposts as weapons against each other, either offensively, as where the importing states imposed tariffs the ultimate incidence of which was calculated to fall on others not blessed by geography with as good and accessible harbors, or defensively, as by strengthening their tariff walls against each other to compensate for revenue deficiencies resulting from diversion of foreign shipments to the states with the least onerous imposts.

Id. at 448-49 (footnotes omitted). See also supra Part II. 
tions," Abel noted, "the same lack of opposition is disclosed." 260

During the debates in Philadelphia, Abel wrote that the references to interstate commerce made there were notable for their "paucity," nevertheless concluded that the Commerce Clause "was uniformly mentioned as a device for preventing obstructive or partial regulations by the states." ${ }^{262}$ In the nine times that Abel found the subject arose, the context was the potential for the Commerce Clause to remedy state predation on one another, mainly through import or export duties or navigation fees, like tonnage duties. ${ }^{263}$ In every instance, however, "the grant of power to Congress was conceived of as preventing states from levying tribute on movements in commerce to and from other states." ${ }^{264}$

There was even less commentary at the state ratifying conventions. Abel discussed a Massachusetts writer who opposed granting commercial regulatory power to Congress, apparently based on the writer's "evident satisfaction with the superior commercial position of his home state" and a desire that "it be allowed to remain in a position to adopt such commercial regulations as it pleased without let or hindrance." ${ }^{265}$ Similarly, advocates of ratification in New York charged opponents with a "reluctance ... to see the revenues arising from commercial exactions, ultimately paid by citizens of neighboring states, slip from their fingers." ${ }^{266}$ These comments, as well as the "occasional references to the chaotic condition of existing commercial relations between the states," Abel wrote, "assumed that adoption of the constitution would terminate the conflicting and prejudicial fiscal burdens

260 Id. at 444. "[F]or the most part, the severest critics of the constitution expressly disclaimed any hostility to [federal control of commerce] and bore testimony that, be the blemishes in other respects what they might, this particular grant of authority was a good and wholesome provision and had their approval." Id. at $\mathbf{4 4 5}$ (footnote omitted).

261 Id. at 470 .

262 ld. at $47 \mathrm{I}$.

263 Abel then broke down the numbers:

In three... instances reference was made to the potentialities of the clause as affording a means of protection against injury inflicted by hostile or harmful restrictions or regulations of sister states, without intimating what particular type of state commercial regulation was thus to be stricken down.... The other six all refer in like manner to the anticipated operation of the grant in preventing discriminatory commercial regulations by states, but mention particular subjects of legislation as being affected. Twice the restraining effect of the grant is mentioned in connection with state export duties. Once it seems to have been involved in an interchange with regard to a state impost on imports.

Id. at $470-71$.

264 Id. at 472.

$265 \mathrm{Id}$.

266 Id. (footnote omitred). 
imposed by the several states on each other's commerce, and ... are in line with the sentiments of the framers."

Combined with Madison and Hamilton's analysis in The Federalist Papers, which "recommended [national control of interstate commerce] as a desirable corrective of state discrimination and as a useful incidental power in the promotion of foreign trade," ${ }^{268}$ Abel concluded that "the extant contemporary evidence ... tends to confirm Pinckney's and Madison's recollection that the power as to commerce between the states was in the main a "negative and preventive provision" and "a shield against state exactions.'

Abel's evidence as to the intent and understanding of the purpose of granting Congress control over interstate commerce strongly suggests that the DCCD could be justified solely on the basis of Article I, Section 8's affirmative grant of power. ${ }^{270}$ But the DCCD need not depend solely on the Commerce Clause for textual and historical support. In the remaining sec-

267 Id. at $472-73$.

268 See id. at 475; see also id. at 474-75. Abel wrote that the analysis in The Federalist Papers:

of the power over commerce between the states comes down to two main propositions. First, state regulations, particularly those of a fiscal nature, were already galling; their removal was essential, as demonstrated by foreign examples and American sentiment, and should be effected by confiding regulation of commerce to the federal government. Second, power over interstate commerce was desirable as a collateral power to the control of foreign commerce, inasmuch as the removal of barriers to interstate trade erected by state restrictions and exactions would extend the available commercial resources and so tend to stabilize mercantile activity.

Id. at 475 .

269 Id. at 475 .

270 DCCD critics might object that Abel's evidence proves only that the withdrawal of power was merely potential, awaiting congressional exercise, and says nothing about judicial enforcement. I discuss this objection infra Part VII.

After I completed this article, I became aware of Professor Calvin Johnson's work on the origins of the Constitution. According to Professor Johnson, the anti-discrimination normthat states should not discriminate against the commerce of other states-was reflected in the Articles of Confederation, and "was strongly felt, but unchallenged and so not written down in the Constitution." Calvin H. Johnson, Homage to Clio: The Historical Continuities from the Articles of Confederation into the Constitution, 20 Const. COMmENT. 463, 463 (2003-2004). Professor Johnson also argues, with Abel, that the scope of Congress' commerce power was fairly limited, given the existence and acceptance of that norm. See generally Calvin H. Johnson, The Panda's Thumb: The Modest and Mercantilist Original Meaning of the Commerce Clause, I 3 WM. \& MARY Bill RTs. J. I (2004). He would thus disagree with my assertion that the Commerce Clause was intended to serve as a significant restraint on the states. See generally Calvin H. JoHNSON, Righteous Anger at the Wicked States: The Meaning of the Founders' Constitution (2005). While we both agree that there is nothing illegitimate about the DCCD, I think we disagree as to the widespread adherence to the norm of non-discrimination during the Confederation period and the extent to which the principle ended up being reflected in the Constitution's text. 
tions, I discuss explicit textual restrictions on state commercial power that nicely complement the affirmative grant of congressional power. Taken together, the combination of grants and restrictions provide ample support for what the Court has been enforcing under the DCCD.

2. The Import-Export Clause. ${ }^{271}$-The Import-Export Clause was tailormade for the paradigm case of state discrimination against imports from and exports to other states, as well as to and from other countries. Critics of the DCCD who claim that if the Commerce Clause was meant to be exclusive there would have been a corresponding restriction on the states in Article I, Section Io completely ignore the Import-Export Clause, which is the most natural textual locus for the anti-discrimination principle. ${ }^{272}$ One reason for this lack of attention must be the assumption that imports and $e x-$ ports refer exclusively to goods that come into the country from outside the United States. Indeed this was the erroneous reading given to the Clause by the Supreme Court in the 1869 case of Woodruff $v$. Parham. ${ }^{273}$ In that case-and contrary to a previous decision written by Chief Justice Taney, who in turn relied on dictum from Chief Justice Marshall-Justice Miller concluded that it was "reasonable to suppose that the general usage" of the terms import and export in 1869 was the same as that during the framing era and that those terms excluded interstate imports and exports. ${ }^{274}$

As many others ${ }^{275}$ (myself included) ${ }^{276}$ have argued, the Woodruff Court's assumption was completely mistaken. The survey of state commercial leg-

27I The discussion in this section draws on that in Brannon P. Denning, Justice Thomas, the Import-Export Clause, and Camps Newfound/Owatonna v. Harrison, 70 U. Colo. L. Rev. 155 (1999).

272 Justice Thomas, as noted above, is an exception.

273 Woodruff v. Parham, 75 U.S. (8 Wall.) 123 ( 1869 ). For a complete discussion of the case and a critique of its reasoning, see Denning, supra note 271, at 162-63, 182-215.

274 Woodruff, 75 U.S. (8 Wall.) at 131 . Compare id. with Almy v. California, 65 U.S. (24 How.) 169, 172-74 (186I) (striking down a law requiring tax stamp on bills of lading for gold and silver exported from California "to any point or place without the State"); Brown v. Maryland, 25 U.S. ( 2 Wheat.) 419, 449 (1827) (interpreting the Import-Export Clause to prohibit occupation tax imposed on importers, as applied to an importer engaged in foreign commerce; adding in dicta, that "we suppose the principles laid down in this case, to apply equally to importations from a sister State").

275 See Camps Newfound/Owatonna, Inc. v. Harrison, 520 U.S. 564, 624-25 (Thomas, J., dissenting) (arguing that the Import-Export Clause was intended to apply equally to interstate, as well as foreign commerce); William Winslow Crosskey, i Politics and the Constitution IN The History OF THE United States 297 ( 1953); Drahozal, supra note 218 , at 1 i 76 ("Imports, within the meaning of the Import-Export Clause, should include all goods brought into a state from without. The term certainly includes goods brought from foreign countries into the United States, but its meaning should not be so limited, as the historical record makes clear.") (footnote omitted); E. Parmalee Price, Congress, and the Regulation of Corporations, 19 HaRv. L. Rev. 168, 192 (1906).

276 See Denning, supra note 271 , at 182-215. 
islation above confirms my earlier conclusion that the terms import and $e x$ port could refer either to interstate or foreign commerce. In state statutes passed during the Confederation period, when foreign imports and exports were the only things meant to be covered in a statute, either the word foreign was used, or the statute included a blanket exemption for imports or exports grown or manufactured in other states. Given that the states related to one another as sovereigns at that time, even the use of the word foreign could give rise to misunderstandings. Recall South Carolina's I 783 law imposing "a duty of Five per Centum on all other goods imported into this State from any foreign port, island, or plantation," which it later clarified did not apply to interstate imports, after many such imports had had the impost levied on them. Virginia took the opposite tack, passing an additional statute declaring everything outside the boundaries of Old Dominion to be foreign for purposes of her impost and duty statutes, after some argued that the use of the word foreign implicitly excluded commerce from the other states. ${ }^{277}$

General usage of import and export aside, when one recalls the language from the Dickinson draft of the Articles of Confederation in light of the circumstances facing the delegates in Philadelphia, any latent ambiguity in the Import-Export Clause evaporates. Dickinson had sought to prohibit all "Duties or Imposts on the Importation of the Productions or Manufactures of another Colony," but left the states free to impose duties and impost on foreign commerce, as long as such impositions did not violate any treaty of the United States. ${ }^{278}$ Experience taught the necessity of restraining states in both interstate and foreign commerce. Article I, Section Io, reflected the lessons learned and made no distinction between interstate and foreign imports or exports. A contemporary reader would naturally have inferred that both types of commerce were beyond the states' reach. In fact, "in its primordial form the prohibition of state imposts appeared merely as a qualifying clause in a section of the commerce clause," that the prohibition extended to interstate as well as foreign commerce and the idea Professor Frankfurter found so heretical: that the Commerce Clause constrained state power as well as empowered Congress.

3. The Tonnage Clause.-Article I, Section io also contains a prohibition-similar to Dickinson's suggested prohibition on "fees for Entries [or] Clearances... relative to Importation or Exportation" ${ }^{280}-$ on duties of tonnage laid by states without congressional consent. Tonnage duties were laid on the carrying capacity of ships and were a popular method of

277 For discussion of both statutes, see Part IV supra.

278 See supra notes 228-250 and accompanying text.

279 Abel, supra note $25^{8}$, at $45^{\circ}$.

280 See supra note 233 and accompanying text. 
raising revenue during the Confederation period. ${ }^{281}$ This clause was added at the Philadelphia Convention to settle an interpretive dispute that had arisen concerning whether the Commerce Clause, by itself, forbade the states from levying tonnage duties to offset, for example, the cost of erecting lighthouses along the coast.

At the convention, the delegates from Maryland moved that a clause be added to allow states to lay tonnage duties "for the purpose of clearing harbours and erecting light-houses." ${ }^{283}$ Gouverneur Morris noted that as the draft of the Constitution then stood, states were not forbidden to lay tonnage duties, and the Maryland proposal might, by negative implication, further restrain the states' power. ${ }^{284}$ Madison responded that whether states were already restrained or not depended upon the scope of the Commerce Clause. While "[r]hese terms are vague," he allowed, they "seem to exclude this power of the States." ${ }^{285}$ John Langdon of New Hampshire then "insisted that the regulation of tonnage was an essential part of the regulation of trade, and that the States ought to have nothing to do with it," and proposed the language of the Tonnage Clause, which then passed 6 to $4 .{ }^{286}$ Langdon's response was directed at Roger Sherman, who remarked that he thought the power over commerce could exist concurrently in the states and Congress, and that "[t]he power of the U[nited] States to regulate trade being supreme can controul [sic] interferences of the State regulations" when and if they occurred. ${ }^{287}$ Sherman's arguments failed to convince a majority of the Convention.

The Tonnage Clause was a sensible supplement to the Import-Export Clause. Without it, states could have evaded the Import-Export Clause by levying duties on ships from out of state, or from foreign countries. "If the states had been left free to tax the privilege of access by vessels to their harbors the prohibition [of the Import-Export Clause] could have been nullified by taxing the vessels transporting the merchandise." ${ }^{288}$

Despite the obvious relationship between the two clauses, unlike the Import-Export Clause, the Tonnage Clause has never been confined to for-

28I See Clyde Mallory Lines v. Alabama ex rel. State Docks Comm'n, 296 U.S. 26I, 265 ( 1935 ) ("duties of tonnage ... were known to commerce as levies upon the privilege of access by vessels ... to the ports or to the territorial limits of a state").

282 See 2 ReCORDs, supra note 253, at 625-26.

$283 \mathrm{Id}$. at 625 .

284 See id.

285 Id. He further commented that "[h]e was more $\&$ more convinced that the regulation of Commerce was in its nature indivisible and ought to be wholly under one authority." Id. (footnote omitted).

286 Id. at 625-26.

287 Id. at 625.

288 Clyde Mallory Lines v. Alabama ex rel. State Docks Comm'n, 296 U.S. 26I, 265 (1935). 
eign commerce, contrary to the Woodruff Court's claim that "duties" were only levied on foreign commerce. ${ }^{289}$ Two years after Woodruff, the Court assumed not only that the Tonnage Clause covered interstate commerce, but also emphasized the connection among the Commerce, Import-Export, and Tonnage Clauses. ${ }^{290}$ Curiously, the State Tonnage Tax Cases made no mention of the recently decided Woodruff case. ${ }^{291}$

4. The Privileges and Immunities Clause of Article IV.-This article, the direct descendant of the Articles of Confederation provision guaranteeing equal rights for trade and commerce, ${ }^{292}$ is another significant limitation on state commercial power and a crucial textual source for the anti-discrimination principle that the Court enforces through the DCCD. Called by Hamilton in The Federalist No. 80 the "basis of the Union," this clause, according to the Supreme Court, is to require from states "substantial equality of treatment for resident[s] and nonresident[s]" unless there exists a "substantial reason" for a distinction that "bears a substantial relationship to the State's objective." ${ }^{294}$ Critics have long urged that the DCCD be discarded in favor of the Privileges and Immunities Clause. ${ }^{295}$ As I have shown elsewhere, though, those anxious to find a textual hook for the DCCD's antidiscrimination principle would have to countenance a host of non-textual doctrinal contortions lest their preferred substitute simultaneously provide less protection against discrimination and impose

289 Woodruff v. Parham, 75 U.S. (8 Wall.) 123, 132 (1869).

290 See State Tonnage Tax Cases, 79 U.S. (12 Wall.) 204, 214-15, 225 (1871); see also Peete v. Morgan, 86 U.S. ( 19 Wall.) 581,584 ( 1873 ) (holding that the Tonnage Clause applies “[m]uch more ... when the vessels are owned by citizens of another State, and are engaged in commerce between the States"); Denning, supra note 271, at 184-86.

291 Denning, supra note 271 , at 185 .

292 See Farrand, supra note 70 , at 127-28 (stating that "the document which proved to be of the most service to [the Committee of Detail charged with fashioning a draft of the Constitution] was the articles of confederation" and that "the insurance of interstate privileges were taken directly from the articles of confederation").

293 The Federalist No. 80, supra note 220, at 478; see also Paul v. Virginia, 75 U.S. (8 Wall.) 168, 180 (1869) (stating that the Clause intended to "place the citizens of each State upon the same footing with citizens of other States" relieving them "from the disabilities of alienage" and "inhibit[ing] discriminating legislation against them by other States").

294 Lunding v. N.Y. Tax Appeals Trib., 522 U.S. 287, 297-298 (1998) (citation omitted); see also Hicklin v. Orbeck, 437 U.S. $518,526-27$ ( 1978 ) (state stature seeking to treat residents and nonresidents differently must be substantially related to solving problem uniquely presented by nonresidents); Toomer v. Witsell, 334 U.S. 385, 395 ( 1948 ) (holding that Clause "was designed to insure to a citizen of State $A$ who ventures into State B the same privileges which the citizens of State B enjoy" including the right to "do[] business in State B on terms of substantial equality" with residents).

295 See Brannon P. Denning, Why the Privileges and Immunities Clause of Article IV Cannot Replace the Dormant Commerce Clause Doctrine, 88 MinN. L. Rev. 384, 385-87 (2003) and sources cited therein. 
greater restrictions on the states and on Congress. Better to view the clause as a supplement to-not a replacement for-the DCCD. ${ }^{296}$

When coupled with the notable lack of controversy over the Commerce Clause $^{297}$ and the power of the Congress to lay and collect taxes, ${ }^{298}$ the commercial restrictions expressed in the text of the Constitution provide a solid textual foundation for the DCCD. The affirmative powers to lay taxes and to regulate commerce, along with the concomitant restrictions placed on the states, map onto the paradigm cases referred to time and again in, inter alia, Madison's correspondence leading up to the Annapolis and the Philadelphia Conventions, and in the state laws that caused him, and others, so much concern.

One does not merely see one clause with one corresponding prohibition, but rather a clause with three direct restraints on state power. The new government needed the ability to prescribe uniform commercial regulations and to secure a source of revenue independent from the states. ${ }^{299}$ In addition, it needed the authority to proscribe certain state actions, undertaken during the Confederation period, which were harmful to the spirit of the union-the discriminatory treatment by certain states toward the commerce of their sister states. Hence, the Import-Export and Tonnage Clauses were born.

This skein of powers and prohibitions related to commerce, in turn, suggests that a much narrower range of power exists for the states to exercise "concurrently" with the federal government. The explicit prohibitions of Article I, Section Io clearly prohibit states from securing local benefits by imposing costs on interstate commerce. In light of the evidence presented above, then-professor Frankfurter's assumption that "an audacious doctrine" like the DCCD "would hardly have been publicly avowed in support of the adoption of the Constitution" and would have occasioned vociferous opposition from those jealous of state sovereignty appears to be incorrect and uninformed. ${ }^{300}$ Justice Scalia in turn adopted Frankfurter's errors when he wrote that it is "beyond question that many 'apprehensions' would have been 'entertained' if supporters of the Constitution had

296 See generally id. at 393-405 (describing problems attending substitution of the Privileges and Immunities Clause of Article IV for the DCCD).

297 The Commerce Clause passed unanimously without recorded debate. See 2 RECORDS, supra note 253 , at 308 ("Clause for regulating commerce with foreign nations \& [interstate commerce] agreed to nem. con.").

298 See id. at 308.

299 FARRAND, supra note 70, at 5 ("Matters of commerce were inseparably associated with those of finance and were at this time of equal moment.").

300 Frankfurter, supta note 256, at ig. 
hinted that the Commerce Clause, despite its language, gave this Court the power it has since assumed." ${ }^{301}$ The evidence presented above points to a conclusion that Justices Scalia and Frankfurter did not consider: that the power to regulate commerce, and even to significantly restrain the states in their regulations of interstate or foreign commerce, was not controversial because most interested parties understood those limitations to be necessary for the continued survival of the union.

\section{Conclusion: Text, History, AND the DCCD}

The apparent consensus in favor of limiting state commercial regulatory power, while broad, was probably not very deep. As Professor Abel put it, "[t]he prevailing tendency ... was to resort to characterization rather than specification." ${ }^{02}$ That there was still some uncertainty about what, exactly, states were prohibited from doing is bolstered by his later surveys of state laws in the quarter century before Gibbons $v$. Ogden, which show states enacting a variety of laws that to one degree or another affected or regulated interstate commerce. ${ }^{303}$ Moreover, it was not entirely clear, in Philadelphia or in the subsequent conventions, to whom the duty of policing the boundaries between federal and state governments would fall, though historian Clinton Rossiter once opined that " $[\mathrm{m}]$ ost delegates, if asked their opinion, would doubtless have said something about the authority of the Supreme Court to declare obnoxious state laws 'null and void." ${ }^{304}$ As it happened, the Supreme Court soon either fulfilled the expectations of the Framers or realized the Constitution's critics' worst fears-depending on one's point of view-by claiming the power to "say what the law is" as part of its judicial power. ${ }^{305}$ It would be the Supreme Court, then, that would have to "implement" ${ }^{306}$ what might now be called an "incompletely theorized" ${ }^{307}$ norm

30 1 Tyler Pipe Indus., Inc. v. Wash. State Dep't of Revenue, 483 U.S. 232, 264 (1987) (Scalia, J., concurring in part and dissenting in part).

302 Abel, supra note 258, at 483 .

303 See, e.g., Albert S. Abel, Commerce Regulation Before Gibbons v. Ogden: Trade and Traffic (pts. I-2), 14 Brook. L. Rev. 38, 215 (1947-48); Albert S. Abel, Commerce Regulation Before Gibbons v. Ogden: Interstate Transportation Facilities, 25 N.C. L. Rev. I2 I (1946-47); Albert S. Abel, Commerce Regulation Before Gibbons v. Ogden: Interstate Transportation Enterprise, 18 Miss. L.J. 335 ( 1946-47).

304 Rossiter, supra note 218 , at 180.

305 Marbury v. Madison, 5 U.S. (I Cranch) 137, 177 (1803).

306 See Richard H. Fallon, Jr., Implementing the Constitution 38 (2001). Fallon explains that "implementation' is a more aptly encompassing term than 'interpretation,' capable of subsuming two conceptually distinctive functions: one of identifying constitutional norms and specifying their meaning and another of crafting doctrine or developing standards of review."

307 See Cass R. Sunstein, Legal Reasoning and Political Conflict 35-6i (1996). 
that states ought not be able to discriminate against the commerce of other states in the Union.

Slowly, haltingly, the Court did just that. By the 1870 , two lines of doctrine emerged: one is the familiar, tortured line addressing the extent to which state regulation of commerce qua commerce was impermissible $;^{308}$ but a second, separate category for state regulations that discriminated against interstate commerce or interstate commercial actors also emerged. ${ }^{309}$ "As the national economy became increasingly integrated in the years following the Civil War, the Court began a conscious and increasingly aggressive campaign to break down local barriers to interstate trade through a 'freetrade' construction of the dormant Commerce Clause."

Improvements in transportation ${ }^{311}$ and the advent of mass-produced goods marketed nationwide spawned state and local efforts to protect their own producers and sellers, to raise revenue at the expense of out-of-staters, or both. ${ }^{312}$ Though similar exactions were not unheard of in earlier years,

308 An historical survey of the doctrinal evolution of the DCCD is beyond the scope of this paper. Suffice it to say that the contortions in this branch of the DCCD arose from the difficulties the early Court had in resolving the question of whether the Commerce Clause had committed to Congress exclusively the power to regulate commerce. The Marshall Court flirted with exclusivity in Gibbons v. Ogden, 22 U.S. (9 Wheat.) I (I 824), and with a distinction between "regulations" of commerce and "mere" exercises of the police powers. Willson $v$. Black Bird Creek Marsh Co., 27 U.S. (2 Pet.) 245 ( 1829). Subsequent courts struggled with the question whether the Commerce Clause independently limited state regulation or whether power was, to some degree, concurrent absent congressional action. See, e.g., David P. CuRRIE, The Constiturion in the Supreme Court: The First Hundred Years, i 789-1888 at 203-06, 222-30 (1985). By mid century, the Court was still struggling with this question, which was answered, if imperfectly, by its Cooley decision, in which the Court announced that states could regulate local subjects, while national subjects requiring a uniform rule were reserved for Congress, whether or not it deigned to act. Cooley v. Bd. of Wardens, 53 U.S. (12 How.) 299 ( 1852 ); CuRrie, supra, at 230-34. Unfortunately, the Court provided little guidance for distinguishing between national and local subjects, so the Cooley rule was gradually supplanted by inquiry into whether a particular measure constitured a "direct" burden on interstate commerce or was merely an "indirect" one. See Boris I. BitTKER, Bittker on the Regulation of INTERstate and Foreign Commerce § 6.04 (1999). This test was itself criticized and was replaced in the 1940s with a frank balancing of local burdens against burdens to interstate commerce-which survives today as "Pike balancing." The test is named for the case in which it was announced, Pike v. Bruce Church Inc., 397 U.S. 137, 142 (1970). Barry Cushman has described in detail how the fashioning and discarding of doctrinal tests was necessary to prevent the irruption of a massive power vacuum occasioned by exclusion of states from certain areas that, given the received wisdom regarding the scope of Congress's positive commerce power, it was not at all clear the federal government could fill. Cushman, supra note 257 , at $1108-20$.

309 See CuRrie, supra note 308, at 404-05.

3 II Cushman, supra note 257, at I 101 .

311 See generally James W. Ely, Jr., "The Railroad System Has Burst Through State Limits": Railroads and Interstate Commerce, 1830-1920, 55 ARK. L. REv. 933 (2003).

312 See, e.g., Vil Charles fairman, History of the Supreme Court of the United States: Reconstruction and Reunion I864-88, pt. 2, at 663-77 (1987); see id. at 664 
in 1876 the Court, expanding on earlier dicta condemning discriminatory taxation, ${ }^{313}$ struck down a Missouri law that imposed a privilege tax on the sale of out-of-state goods. ${ }^{314}$ Historian Charles Fairman commented that the willingness to challenge "exactions of long standing... suggests a new sense of nationalism to which the centennial decision in Welton gave expression." ${ }^{315}$ Over a century later this categorical approach survives, with facially discriminatory taxes and regulations deemed "virtually per se" illegal and subject to strict scrutiny, as are facially neutral regulations with discriminatory effects or motivated by protectionist purpose. ${ }^{316}$ The antidiscrimination principle is also vigorously enforced through the Privileges and Immunities Clause of Article IV, Section 2.

At a minimum, the Supreme Court's use of the DCCD to eliminate overt or covert commercial discrimination against interstate commerce and commercial actors is entirely in keeping with the text of the Constitutionwhich simultaneously delegated power to Congress and withdrew from states powers to discriminate in the grant of commercial "privileges and immunities" or to enact the types of regulations that had spawned abuses during the Confederation era-and the intent of its drafters, as well as being consistent with the understanding of those who were called upon to ratify the Constitution. The men who drafted the Constitution were interested in arresting extant abuses of state commercial power that the Articles were powerless to stop. The centralization of commercial regulatory power and the affirmative limitations on state power were largely (if not universally) understood to be necessary and benevolent. As one for whom text and history are important, as are structure and precedent, I am satisfied that the evidence furnishes no reason to criticize the DCCD for a lack of either textual or historical pedigree. The evidence fatally undermines critics' main objections to the DCCD described in the introduction.

There are at least three other possible objections that one might lodge against my conclusions. First, even in its current form, the DCCD extends

(describing advent of Singer sewing machines and state attempts to license sellers of out-ofstate products); see also 2 Charles Warren, The Supreme Court in United States History 625 (1926) ("With the immense development of the railroad and telegraph systems of the country, the increased facility for the doing of interstate business and the multiplication of commercial corporations after the Civil War, [the Commerce Clause] of the Constitution began to assume an importance in the history of the law which it had never before attained.").

313 See Woodruff v. Parham, 75 U.S. (8 Wall.) I23, I 40 ( I 869). I have criticized Woodruff v. Parham elsewhere for its erroneous conclusion that the Import-Export Clause was intended to apply only to foreign imports and exports. Denning, supra note 271, at 162-63. David Currie argued that this was the first instance in which discrimination was employed by the Court to assess the validity of a state measure under the Commerce Clause. CurRIE, supra note 308, at 337 .

314 Welton v. Missouri, 9I U.S. 275 ( 1876 ).

315 Falrman, supra note 312 , at 666 (footnote omitted).

316 See, e.g., City of Philadelphia v. New Jersey, 437 U.S. 61 7, 624 (1978). 
beyond mere discrimination and potentially invalidates nondiscriminatory regulations of commerce. Second, the current DCCD prohibits state regulations beyond the immediate concerns of the Framers, who worried primarily about financial levies on commerce-taxes, imposts, and the like. Third, even if prohibitions on state power were effected by the grant of commercial power to Congress, nothing in the Constitution authorizes a $j u$ dicial role for striking down state laws that contravene that intended regulatory centralization.

\section{A. Application of DCCD to Nondiscriminatory State Regulations}

Despite Justice Scalia's urgings, ${ }^{317}$ the modern DCCD applies not only to discriminatory regulations, but also to those regulations whose burdens on interstate commerce are "clearly excessive in relation to the [regulations'] putative local benefits." ${ }^{18}$ The so-called Pike balancing test in large part merely restated what the Court had been doing in nondiscriminatory cases for some time. ${ }^{319}$ Even so, such balancing had long been criticized as an improper arrogation of legislative duties. ${ }^{320}$ Such criticisms continue among the DCCD's vocal critics. ${ }^{321}$ A critic might say that the evidence adduced here does nothing to bolster the balancing tier of the DCCD and thus I have done little, as the title promises, to "legitimate" the DCCD.

The simple answer is that the antidiscrimination branch of the DCCD is responsible for the invalidation of state and local laws in the Supreme Court and in the lower courts. According to one recent article, the Court has not relied on Pike balancing in a DCCD case since the 1988 term. $^{322}$ According to my count, ${ }^{323}$ in only eight cases in the last six years have lower

317 See Tyler Pipe Indus. v. Wash. State Dep't of Revenue, 483 U.S. 232, 265 (I987) (Scalia, J., concurring in part and dissenting in part) (urging limitation of DCCD to cases of "rank discrimination").

318 Pike v. Bruce Church, Inc., 397 U.S. I37, 142 (1970); see generally David S. Day, Revisiting Pike: The Origins of the Nondiscrimination Tier of the Dormant Commerce Clause Doctrine, 27 Hamline L. Rev. 45 (2004).

3 I9 See, BitTkeR, supra note 308 , at $\$ 6.05$.

320 See, e.g., S. Pac. Co. v. Arizona, 325 U.S. 761, 784 (1945) (Black, J., dissenting); id. at 795-96 (Douglas, J., dissenting); McCarroll v. Dixie Greyhound Lines, Inc., 309 U.S. 176, 183 (1940) (Black, J., dissenting).

321 See supra note 2.

322 Day, supra note 318 , at $49 \&$ n.20.

323 Yamaha Motor Corp., U.S.A. v. Jim's Motorcycle, Inc., 40 I F.3d 560, 570-74 (4th Cir. 2005) (striking down a provision of Virginia law permitting motorcycle franchise holders to protest intent to establish a competing franchise anywhere else in the state, triggering requirement that manufacturer prove inadequate representation in the market); PSINET, Inc. v. Chapman, 362 F.3d 227, 240 (4th Cir. 2004) (divided court) (striking down Virginia statute prohibiting use of Internet to display or provide access to offensive materials by juveniles; burdens on interstate commerce clearly excessive compared to local benefits); Alliant Energy Corp. v. Bie, 303 F.3d 904, 919 (7th Cir. 2003) (striking down Wisconsin statute requiring that 
federal courts used Pike balancing to strike down state regulations, though many Pike challenges have been brought and rejected. ${ }^{324}$ Thus, whether or not Professor Regan's provocative thesis-that even when courts apply Pike balancing, they are really looking for protectionist purpose ${ }^{325}$-is true or not, it is clear that the courts themselves have of late wielded the DCCD primarily as a sword against discriminatory and protectionist state legislation.

Despite the reluctance of courts to invalidate non-discriminatory, yet arguably burdensome, state laws under Pike, I am not as sure as I once was that some balancing of national and local interests is inappropriate, even for courts. The evidence assembled by Professor Abel tends to support the idea that the Framers had some notion that the grant of power

utilities holding companies be incorporated in the state of Wisconsin; concluding that burden on interstate commerce outweighs any local benefits, but upholding provision prohibiting transfer of utility license to foreign corporation and provisions regarding take-over of utilities); R \& M Oil \& Supply, Inc. v. Saunders, 307 F.3d 73I, 735-36 (8th Cir. 2002) (striking down Missouri law requiring bulk propane sellers to maintain-but not necessarily to fill or use-an 18,00o-gallon storage tank in the state; burden on interstate commerce excessive as compared to de minimis local benefits); S.E. Booksellers Ass'n v. McMaster, 37 I F. Supp. 2d 773, 786-88 (D.S.C. 2005) (holding that a South Carolina statute prohibiting dissemination of material "harmful to minors" over the Internet is invalid "because the burdens that it imposes on interstate commerce are excessive in relation to the local benefit conferred"); Ctr. for Democracy \& Tech. v. Pappert, 337 F. Supp. 2d 606, 662 (E.D. Pa. 2004) (striking down state law requiring Internet service providers to remove or disable access to child pornography either stored on or available through its service; little evidence law is effective while "there is evidence that this Act places a substantial burden on interstate commerce"); Kraft Foods N. Am., Inc. v. Rockland Co. Dep't Weights \& Measures, No. ol Giv. 6980 (WHP), 2003 WL 554796, at *8-10 (S.D.N.Y. Feb. 26, 2003) (striking down county's method of enforcing state food labeling requirements that required weights on packages to meet or exceed weight on box under Pike balancing); Dakota, Minnesota \& E. R.R. Corp. v. South Dakota, 236 F. Supp. $2 \mathrm{~d} 989,1020-24$ (D.S.D. 2002) (striking down part of state statute requiring railroad have financial resources necessary to complete expansion project to exercise power of eminent domain). Two other district courts whose decisions invoked Pike to invalidate state laws were later overturned. See Phillip Morris, Inc. v. Reilly, I 3 F. Supp. 2d I 29, 146-5 I (D. Mass. 200o) (striking down Massachusetts statute requiring tobacco companies to file disclosure statements detailing ingredients and nicotine yield of cigarettes), rev'd 267 F.3d 45 (Ist Cir. 2002) (withdrawn from bound volume at the request of the court); Nat'l Elec. Mfg. Ass'n v. Sorrell, 77 F. Supp. 2d 449, 450, 454-55 (D. Vt. 1999) (enjoining enforcement of Vermont statute forbidding sale of items containing mercury without warning label), rev'd $272 \mathrm{~F} .3 \mathrm{~d}$ 103 (2d Cir. 2001).

324 For cases in which Pike challenges were rejected, see Boris I. BitTKer \& Brannon P. Denning, Bittker on the Regulation of Interstate and Foreign Commerce, 2005 Cumulative Supplement § 6.05, at 132-39 (2005). See also Boris I. Bittker \& Brannon P. Denning, Bittker on the Regulation of Interstate and Foreign Commerce, 2006 Cumulative Supplement § 6.05 (forthcoming).

325 See Donald H. Regan, The Supreme Court and State Protectionism: Making Sense of the Dormant Commerce Clause, 84 MicH. L. Rev. 1091 , 1092 (1986) ("In the central area of dormant commerce clause jurisprudence, ... the Court has been concerned exclusively with preventing states from engaging in purposeful economic protectionism."). 
to Congress of commercial regulatory power (which Abel argues was understood to be of relatively narrow scope) excluded the states from that area. ${ }^{326}$ Moreover, note the absence in the text of Article I, Section Io of any mention of "discriminatory" tonnage fees or "discriminatory" imposts and duties on imports and exports. One might conclude, as the Court once held, that states were prohibited from levying any kind of burden whatsoever on any "interstate commerce" that passed through its borders. ${ }^{327}$ Clearly, as others have shown, that would have deprived the states of a great deal of revenue, just as any total exclusion of states from regulation of "interstate commerce"-given how that concept has expanded over the years-would have hobbled states' historical police powers.

Though it is true that The Federalist No. 32 did not list the commerce power among those powers given exclusively to Congress, it did note that power was denied to states when their exercise of it would be "repugnant" to the national plan. ${ }^{328}$ Chief Justice Marshall surely followed Hamilton, and perhaps anticipated Cooley, when he concluded that the paradigmatic "concurrent[]" power-that of taxation-could not be exercised by states in a manner contrary to the purpose of the Union. ${ }^{329}$ If one of the purposes of placing power over commerce in Congress included promoting uniformity and consistency, Pike balancing, then, is merely the latest attempt to give substance to Justice Curtis's intuitively appealing distinction between "national" subjects for which one rule should prevail and "local" subjects that could tolerate varied local rules. ${ }^{33^{\circ}}$ To criticize the way in which the Court has implemented this norm is not the same as proving that the norm was invented by later courts or otherwise violated the expectations of those who wrote or enacted the Constitution.

\section{B. Expansion of DCCD to Cover Regulations}

Of course, the DCCD has been wielded against measures that involve regulations as opposed to literal imposts, duties, fees, or other taxes. ${ }^{331}$ Justice

326 See Abel, supra note 258, at 432.

327 Brown v. Maryland, 25 U.S. ( 12 Wheat.) 419 (1827) (suggesting tax immunity for goods in interstate commerce that were still in their original packages). But see Michelin Tire Corp. v. Wages, 423 U.S. 276 (1976) (rejecting the original-package doctrine). 1961).

328 The Federalist No. 32, at 198-200 (Alexander Hamilton) (Clinton Rossiter ed.,

329 M'Culloch v. Maryland, 17 U.S. (4 Wheat.) 316,425 (1819).

330 Cooley v. Bd. of Wardens, 53 U.S. ( 2 How.) 299, 319 (1852).

331 See, e.g., C \& A Carbone, Inc. v. Town of Clarkstown, 5 I I U.S. 383 (1994) (invalidating local "flow control" ordinance prohibiting export of solid waste and requiring disposal at townoperated facility); Wyoming v. Oklahoma, 502 U.S. 437 (1992) (striking down state statute requiring coal-fired electric plants to burn coal containing at least ten-percent in-state coal); CTS Corp. v. Dynamics Corp. of Am., 48ı U.S. 69 (1987) (presenting a DCCD challenge to anti-takeover statute); Maine v. Taylor, 477 U.S. 13 I (1986) (state ban on the importation of 
Stevens recently wrote that while "[ $t]$ he paradigmatic example of a law discriminating against interstate commerce is the protective tariff or customs duty, which taxes goods imported from other States, but does not tax similar products produced in State," such tariffs "are so patently unconstitutional that our cases reveal not a single attempt by any State to enact one. Instead, the cases are filled with state laws that aspire to reap some of the benefits of tariffs by other means. ${ }^{332}$ Has the Court's extension of the DCCD to regulations - even the antidiscrimination principle-rendered the doctrine suspect or caused it to slip too far from its textual and historical moorings?

I am hard-pressed to see how. Forbidding only the modern tax equivalents of "imposts" and "duties" or "duties of tonnage" and permitting, for example, a state regulation requiring that all in-state goods destined for export be subject to some in-state processing requirement would be a triumph of form over substance. ${ }^{333}$ To permit states merely to repackage discriminatory taxes as burdensome or expensive regulations and employ them to enrich their own trade at their neighbors' expense, with all of the attendant injury to interstate relations and cycles of retaliation, would fatally undermine what was the key purpose for centralizing trade regulation.

Moreover, the language of the Constitution itself supports the Court's extension. Article I, Section 8 grants the power to regulate "commerce" among the states, not just the power to standardize tariffs. Similarly, the term privileges and immunities in Article IV, Section 2, and the earlier Article of Confederation provision from which it was derived, seems to sweep more broadly than a simple guarantee against burdensome taxes.

Finally, when it comes to the elimination of barriers to trade that so worried the Framers, the Court, as Alexander Bickel put it, has been "no respecter of disguise." ${ }^{334}$ There is venerable precedent that counsels against

baitfish challenged under DCCD); Sporhase v. Nebraska, $45^{8}$ U.S. 94 I (I982) (striking down state restrictions on exportation of groundwater to neighboring states); Hunt v. Wash. State Apple Adver. Comm'n, 432 U.S. 333 (1977) (invalidating state labeling requirements); H.P. Hood \& Sons, Inc. v. DuMond, 336 U.S. 525 ( 1949 ) (striking down ban on importation of milk at lower than state-approved prices); Edwards v. California, 3 I 4 U.S. I 60 (194I) (striking down California law prohibiting the importation of "indigents"); Baldwin v. G.A.F. Seelig, Inc., 294 U.S. 5 I I ( 1935); Foster-Fountain Packing Co. v. Haydel, 278 U.S. I (1928) (striking down instate processing requirement for shrimp caught in local waters).

332 West Lynn Creamery, Inc. v. Healy, 512 U.S. 186, 193 (1994).

333 It was on this "form-over-substance" ground that I criticized Justice Thomas's suggestion to scrap the DCCD, replace it with judicial enforcement of the Import-Export Clause, but restrict the Import-Export Clause's enforcement to those state taxes that were literally the imposts and duties forbidden by the clause. Justice Thomas never articulated a difference between those taxes and other sorts of discriminatory regulations, other than by adverting to the text's use of "imposts" and "duties," see Denning, supra note 271, at 215-23, and implying that if that is all the text covered, then he had no authority to read those at a higher level of abstraction.

334 IX Alexander M. Bickel \& Benno C. Schmidt, Jr., History of the Supreme 
wooden literalism in the reading of these provisions. The Court, interpreting both the Import-Export Clause ${ }^{335}$ as well as the Tonnage Clause, ${ }^{336}$ has enforced those provisions with regard for their intended purpose, casting a chary eye on state attempts to evade the literal language of the provisions. ${ }^{337}$ The evolution of the DCCD's scope is at least as reasonable.

By extending the scope of DCCD to regulations as well as taxation the Court has taken no more liberty than when it extended the First Amendment to all branches of the government, not just Congress, ${ }^{338}$ or to certain forms of symbolic conduct, ${ }^{339}$ or when the Fourth Amendment's

Court of the United Ștates: The Judiciary and Responsible Government, 19 IO-2 I, at 568 (1984).

335 When California imposed a tax on bills of lading for gold and silver to be shipped anywhere out of the state, Chief Justice Taney struck it down under the Import-Export Clause despite the fact that the tax was not literally on the gold and silver itself. Almy v. California, 65 U.S. (24 How.) I 69 (186 I). "If the tax was laid on the gold or silver exported," wrote Taney, "every one would see that it was repugnant" to the Clause. Id. at 173. The question was whether the indirect nature of the tax insulated it from the strictures of the Clause. For Taney, it did not: "[A] tax or duty on a bill of lading, although differing in substance from a duty on the article shipped, is in substance the same thing." Id. at 174 .

336 In 1867 , the Supreme Court struck down a flat fee imposed by the City of New Orleans on ships entering the Port of New Orleans as a violation of the Tonnage Clause. See Steamship Co. v. Portwardens, 73 U.S. (6 Wall.) 31 (1867). Despite the fact that the tax was not levied on the carrying capacity of the ship, Chief Justice Chase held that the Clause prohibited not only "a pro rata tax" but "any duty on the ship, whether a fixed sum upon its whole tonnage, or a sum to be ascertained by comparing the amount of tonnage with the rate of duty." Id. at 34-35. If the Clause were interpreted "in this restricted sense," i.e., only forbidding a pro rata imposition, it "would not fully accomplish its intent." Id.

337

It is a just and well-settled doctrine... that a State cannot do that indirectly what she is forbidden... to do directly. If she cannot levy a duty or tax from the master or owner of a vessel engaged in commerce graduated on the tonnage or admeasurement of the vessel, she cannot effect the same purpose by merely changing the ratio, and graduating it on the number of masts, or of mariners, the size or power of the steamengine, or the number of passengers which she carries.

The Passenger Cases, 48 U.S. (7 How.) 283, 458-59 ( 849 ).

338 Compare U.S. Const. amend. I ("Congress shall make no law") (emphasis added) with N.Y. Times Co. v. United States, 403 U.S. 713 (197I) (per curiam) (holding that the First Amendment applies to the executive branch). See also Daniel A. Farber, The First Amendment I (2d. ed. 2003) (noting that "free expression is also protected against abridgement by the President and the federal courts."); Mark P. Denbeaux, The First Word of the First Amendment, 80 Nw. U. L. Rev. 1156 ( 1987 ) (discussing the evolution of First Amendment protection from Congress to other branches).

339 See, e.g., Texas v. Johnson, 49I U.S. 397 (1989) (holding that burning the American flag was expressive activity protected by the First Amendment); Cohen v. California, 403 U.S. 15 (1971) (applying First Amendment to jacket emblazoned with message opposing the draft); Tinker v. Des Moines Indep. Sch. Dist., 393 U.S. 503 ( r 969) (holding that First Amendment protects right to wear armbands symbolizing opposition to Vietnam War); United States v. O'Brien, 391 U.S. 367 ( 1968) (discussing First Amendment protection for symbolic speech). 
protections of "persons, houses, papers, and effects, against unreasonable searches and seizures" are held to keep pace with the advance of technology. ${ }^{340}$ If there is a difference between these examples of stretching language to enforce a constitutional principle, and the evolution of the DCCD, it is not apparent, and the DCCD's critics ought to explain it.

\section{Lack of Authority for a Judicial Role}

Finally, the claim exists that whatever limits the Commerce Clause did or did not place on states, it is for Congress, not the federal courts, to enforce those limitations. ${ }^{341}$ The Commerce Clause, critics point out, says nothing about being enforced by courts. ${ }^{342}$ This criticism misses the mark for two reasons. First, it proves too much. The Constitution says precious little about an affirmative judicial role in enforcing any of the Constitution's provisions; yet, judicial review has survived-thrived, really- for two centuries. Moreover, while the Constitution does not specifically mention judicial review, the possibility of judicial enforcement was clearly on the minds of the Framers and was feared by the Constitution's opponents.

Second, the "no-judicial-power-to-enforce" argument focuses too narrowly on the Commerce Clause as the sole source of the principles embodied in the DCCD. Consider the Privileges and Immunities Clause of Article IV, Section 2: nothing in that provision explicitly mentions judicial enforcement either, yet Justice Scalia and other DCCD critics support it as the locus for judicial enforcement of the nondiscrimination principle. The provisions of Article I, Section Io-clearly meant to limit states-also contain no provision for their enforcement, but would be useless without court enforcement. The defense that I have offered above avoids the need to rely on a specific piece of text. Both the grant of power to regulate commerce and the corresponding restrictions on states were made for a purpose, evidenced not in a single clause but in an interrelated set of grants and restrictions, and the Court has enforced those purposes fairly consistently through the DCCD. If critics were consistent, one might expect they would be equally bothered by other structural restrictions, like sovereign immunity or the "anticommandeering principle," which are built upon

340 Compare U.S. ConsT. amend. IV (guaranteeing security in "persons, houses, papers, and effects" against "unreasonable searches and seizures"), with Katz v. United States, 389 U.S. 347 (1967), and Berger v. New York, 388 U.S. 41 (1967) (extending Fourth Amendment protection to conversations intercepted by wiretaps).

341 See, e.g., Tyler Pipe Indus. v. Wash. State Dep't of Revenue, 483 U.S. 232, 260 (1987) (Scalia, J., concurring in part and dissenting in part) (discussing the "lack of any clear theoretical underpinning for judicial 'enforcement' of the Commerce Clause," which is "[o]n its face ... a charter for Congress, not the courts"). Id. at 260.

342 See id. 
slight textual evidence, but which are nevertheless vigorously enforced by the present Court.

Finally, it is worth pointing out, as Jim Chen did recently, ${ }^{343}$ that Congress has had the power for nearly 150 years to halt judicial enforcement of the DCCD through the use of its affirmative commerce power. That it has chosen to do so very rarely suggests at least an indifference to, if not acquiescence in, the judicial role that even Justice Scalia has conceded is tantamount to "intellectual adverse possession." 344

343 Jim Chen, $A$ Vision Softly Creeping: Congressional Acquiescence and the Dormant Commerce Clause, 88 Minn. L. Rev. 1764, 1784 (2004). But see Norman Williams, Why Congress May Not Overrule the Dormant Commerce Clause, 53 UCLA L. REv. I 53 (2005).

344 Tyler Pipe Indus., 483 U.S. at 265 (Scalia, J., concurring in part and dissenting in part). 
